\title{
Inhibition of phosphotidylinositol-3 kinase pathway by a novel naphthol derivative of betulinic acid induces cell cycle arrest and apoptosis in cancer cells of different origin
}

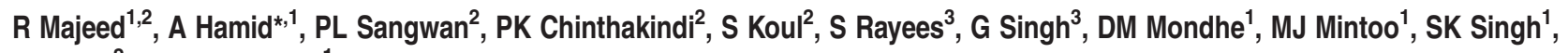 \\ SK Rath ${ }^{2}$ and AK Saxena ${ }^{1}$
}

Betulinic acid (BA) is a pentacyclic triterpenoid natural product reported to inhibit cell growth in a variety of cancers. However, the further clinical development of BA got hampered because of poor solubility and pharmacological properties. Interestingly, this molecule offer several hotspots for structural modifications in order to address its associated issues. In our endeavor, we selected C-3 position for the desirable chemical modification in order to improve its cytotoxic and pharmacological potential and prepared a library of different triazoline derivatives of BA. Among them, we previously reported the identification of a potential molecule, that is, 3\{1N(5-hydroxy-naphth-1yl)-1H-1,2,3-triazol-4yl\}methyloxy betulinic acid (HBA) with significant inhibition of cancer cell growth and their properties. In the present study, we have shown for the first time that HBA decreased the expression of phosphotidylinositol-3 kinase (PI3K) p110 $\alpha$ and p85 $\alpha$ and caused significant downregulation of pAKT and of NF $k$ B using human leukemia and breast cancer cells as in vitro models. Further it was revealed that PI3K inhibition by HBA induced cell cycle arrest via effects on different cell cycle regulatory proteins that include CDKis cyclins and pGSK3 $\beta$. Also, this target-specific inhibition was associated with mitochondrial apoptosis as was reflected by the increased expression of mitochondrial bax, downregulated bcl2 and decreased mitochondrial levels of cytochrome $c$, together with reactive oxygen species generation and decline in mitochondrial membrane potential. The apoptotic effectors such as caspase 8, caspase 9 and caspase 3 were found to be upregulated besides DNA repair-associated enzyme, that is, PARP cleavage caused cancer cell death. Pharmacodynamic evaluation revealed that both HBA and BA were safe upto the dose of $2000 \mathrm{mg} / \mathrm{kg}$ body weight and with acceptable pharmacodynamic parameters. The in vitro data corroborated with in vivo anticancer activity wherein Ehrlich solid tumor showed that HBA as a more potent agent than BA without any body weight loss and mortality.

Cell Death and Disease (2014) 5, e1459; doi:10.1038/cddis.2014.387; published online 9 October 2014

Natural products isolated from plant sources have been used extensively in traditional medicine for the treatment of innumerable diseases. ${ }^{1,2}$ Within the sphere of cancer, a number of important new commercialized drugs have been obtained from natural sources either by structural modification of natural compounds or by the synthesis of new compounds using natural compound as model. ${ }^{3}$ The huge structural diversity of natural compounds and their bioactivity potential have meant that several products isolated from plants can serve as lead compounds for improvement of their therapeutic potential by molecular modification. ${ }^{4}$ Betulinic acid (BA) is a naturally occurring triterpenoid with a potential of inducing apoptosis in a variety of malignancies and show remarkable selectivity for tumor cells over non-transformed cells. ${ }^{5}$ The proapoptotic effects of BA have been characterized by several markers of apoptosis, including cleavage of various caspases and the nuclear protein poly-ADP ribose polymerase (PARP). ${ }^{6}$
BA has been reported to induce cancer death via induction of mitochondrial apoptotic pathway. ${ }^{7}$ It shows inhibition of protein specificity transcription factors, activates the stress kinases p38, acts as potent inhibitor of mammalian type 1 DNA topoisomerase, inhibits transcription factor nuclear factor kappa B (NFKB) and shows apoptosis in a p53- and CD95independent manner. ${ }^{8-10}$ In addition, triterpenoids are reported to induce cell cycle arrest and apoptosis via the modulation of phosphotidylinositol-3 kinase (PI3K)/AKT pathway, for example, Tanshinone IIA, (Tan IIA) reduced the expression PI3K p85 subunit, and the phosphorylation of AKT and mammalian target of rapamycin in a concentrationdependent manner. The PI3K signaling pathway has established the central role in several cellular processes critical for cancer cell proliferation, including growth, survival, motility, cell cycle progression and metabolism. ${ }^{11}$ Moreover, there are reports that demonstrate the modulation of bcl-2, bax, cyclin

\footnotetext{
${ }^{1}$ Cancer Pharmacology Division, CSIR-Indian Institute of Integrative Medicine, Jammu, India; ${ }^{2}$ Bio-organic Chemistry Division, CSIR-Indian Institute of Integrative Medicine, Jammu, India and ${ }^{3}$ PK-PD Division, CSIR-Indian Institute of Integrative Medicine, Jammu, India

${ }^{*}$ Corresponding author: A Hamid, Cancer Pharmacology Division, CSIR-Indian Institute of Integrative Medicine, Canal Road, Jammu, Tawi 180001, India. Tel: +91 191 2569001 extn 352; Fax: +91 191 2569333; E-mail: ahdar@iiim.ac.in

Abbreviations: BA, betulinic acid; DCFH-DA, 2',7'-dichlorfluorescein-diacetate; HBA, 3\{1N(5-hydroxy-naphth-1yl)-1H-1,2,3-triazol-4yl\}methyloxy betulinic acid; MTT, 3-(4,5-dimethylthiazole-2-yl)-2,5-diphenyltetrazolium bromide; NF $\kappa$ B, nuclear factor kappa B; PI3K, phosphotidylinositol-3 kinase; PI, propidium iodide; ROS, reactive oxygen species; Rh-123, Rhodamine-123

Received 29.11.13; revised 24.6.14; accepted 10.7.14; Edited by A Finazzi-Agrò
} 
D1 and pGSK3 $\beta$ expression after BA treatment in several cancer cell lines. ${ }^{12}$ GSK3 $\beta$ is a substrate of the PI3K/AKT pathway that is constitutively active in unstimulated cells, and AKT is the kinase primarily responsible for phosphorylation of GSK3 $\beta$ at Ser. ${ }^{9}$ There is growing evidences which support the notion that the activation of PI3K/AKT is associated with different events of leukemia and breast cancer and also that class I PI3Ks are highly expressed in breast cancer cell lines and particularly $\mathrm{p} 110 a$ representing PI3Ka enzyme. ${ }^{13,14}$ However, no report has been found suggesting inhibition of $\mathrm{PI}$ KK/AKT pathway by BA or any of its structural analogs till date. In spite of tremendous biological activities, further clinical development of BA is greatly hampered because of its poor solubility and poor pharmacokinetic properties. ${ }^{15} \mathrm{BA}$ has also been reported to show weak metabolic stability with $>60 \%$ of the compound getting metabolized leading to low plasma concentrations. The poor permeability coupled with poor aqueous solubility suggests that these compounds may be unsuitable for oral administration. ${ }^{16}$ Therefore much work has been focused on modification of BA on the C-3 and/or C-28 positions in order to increase its hydro solubility and thereby possibly biological properties. ${ }^{17,18}$ In this context, C-3modified BA derivatives proved to have better in vivo antitumor efficacy as compared with BA. ${ }^{19}$

With our success toward the synthesis of a library of semisynthetic analogs of BA to achieve better efficacy and lesser toxicity, chemical modification was done by targeting position 3 of ring $A$ (Figure 1a), one of the hot spots of the molecule which could lead to the generation of a triazole derivative $(3\{1 \mathrm{~N} / 5$ hydroxy-naphth-1yl)-1H-1,2,3-triazol-4y/\}methyloxy betulinic acid (HBA)) of BA, the potent anticancer candidate with significant apoptotic effects. ${ }^{20}$ Triazole compounds has attracted considerable attention for the past few decades due to their chemotherapeutical value ${ }^{21}$ due to which the anticancer potential of HBA became obvious. However, the molecular mechanism behind its functioning is still not clear. In this communication, we have tried to evaluate the mechanistic role of HBA, a hydroxyl derivative of BA, on apoptosis and cell cycle under in vitro conditions and also to evaluate the pharmacodynamics profile besides tumor regression potential of HBA in comparison to BA under in vivo conditions.

\section{Results}

Cytotoxicity profile of BA and its derivatives. BA and its different structural analogs were screened against different human cancer cell lines to evaluate their cytotoxic effect. During preliminary screening at $50 \mu \mathrm{M}$ concentration, most of the cancer cell lines were found to be sensitive to BA and its derivatives, with many of them exhibiting $\geq 90$ inhibition against various cancer cell lines. At $10 \mu \mathrm{M}$ concentration, BA was not found to be toxic against any of the cancer cell line. However, many of its derivatives produced concentrationdependent growth inhibition on several cancer cell lines. Leukemia cells (HL-60 and THP-1) and breast cancer cells (MCF-7) proved most sensitive toward the semi-synthetic analogs, in particular HBA showing highly significant cytotoxic effect. ${ }^{20}$ The antiproliferative effects of HBA was further investigated in HL-60, THP-1 and MCF-7 cells in order to get the concentration- and time-dependent $I_{50}$ values. Treatment of all the three cell lines with HBA produced concentration- and time-dependent inhibition of cell proliferation, with $I_{50}$ values of approximately 1.9, 12 and 23, 5.3, 12, 22 and 5.8, 10 and $23 \mu \mathrm{M}$ at 48,24 and $12 \mathrm{~h}$ on HL-60, THP-1 and MCF-7, respectively (Figures $1 \mathrm{~b}-\mathrm{d}$ ). HBA has been found to inhibit colony formation in THP-1 cells as reported previously by us. In the present case, we have found that MCF-7 cells have also been restricted for their colony-formation capability at 10 and $20 \mu \mathrm{M}$ concentrations.

HBA-mediated downregulation in the expression of PI3K p110a, p85a and pAKT in HL-60, THP-1 and MCF-7 cells. The PI3K signaling pathway has the central role in several cellular processes critical for cancer cell proliferation, including metabolism, growth, survival, motility and cell cycle progression. $^{22}$ Keeping this in view, we evaluated the expression of p110a and p85 isoforms of PI3K in HL-60, THP-1 and MCF-7 cells. We found significant downregulation of both p110a and p85a isoforms of PI3K even at low micromolar concentration of HBA in all the three cancer cell lines (Figures $2 a-c$ ). Further, significant reduction in the phosphorylated AKT (pAKT) protein expression has been observed in all the three cancer cell lines, which is the most immediate substrate of PI3K. However, we could not address any significant changes in the total AKT (tAKT) levels. BA caused significant decrease in the expression of PI3K p110a, p85 and pAKT but at very higher concentration, that is, 50,70 and $100 \mu \mathrm{M}$ in HL-60 and MCF-7 cells (Figures $2 \mathrm{~d}$ and e). At $30 \mu \mathrm{M}$, BA could not downregulate any of the three proteins; however, at this concentration HBA has downregulated all the three proteins significantly. BEZ-235 a well-known dual PI3K/AKT inhibitor, ${ }^{23}$ was used as a positive control to validate the results that produced significant PI3K p110a and p85a and PAKT inhibition when used at $50 \mathrm{nM}$ concentration.

HBA-induced downregulation in the expression of cell cycle regulators cyclins D, E and A. Deregulated cell cycle control is a fundamental aspect of cancer; ${ }^{24}$ therefore we were intended to look into the expression level of the different cyclins. Expression studies done using HL-60, THP-1 and MCF-7 cells revealed downregulation in the expression of cyclins $D, E$ and $A$ in a concentration-dependent manner (Figures $3 a-c$ ). In the HL-60 and THP-1 cells compared with the untreated control, cyclin $\mathrm{D}$ protein levels were significantly decreased (Figures $3 a$ and b). In MCF-7 cells, the cyclin D expression got significantly decreased even at lower concentration (Figure 3c). In THP-1 cells, the parent BA molecule could not downregulate cyclin $\mathrm{D}$ even at $30 \mu \mathrm{M}$ concentration (Figure $3 b$ ). The cyclin $\mathrm{E}$ protein is an important cell cycle regulator and is primarily detected during the late $\mathrm{G} 1$ phase of the cell cycle. In the present study, we have found significant decrease in the expression of cyclin $E$ protein in HL-60, THP-1 and MCF-7 cells treated with the indicated concentrations of HBA (Figures $3 a-c)$. BA also caused moderate changes in the expression of cyclin $\mathrm{E}$ protein at $30 \mu \mathrm{M}$ concentration (Figure $3 \mathrm{~b}$ ). The overexpression of cyclin $A$ has been linked to the development and progression of majority of cancers. ${ }^{25}$ In HL-60 cells, treatment with HBA 
<smiles>C=C(C)[C@H]1CC[C@]2(C(=O)O)CCC3C(CCC4[C@@]3(C)CCC3C(C)(C)[C@@H](OCc5cn(-c6cccc7c(O)cccc67)nn5)CC[C@@]34C)C12</smiles>

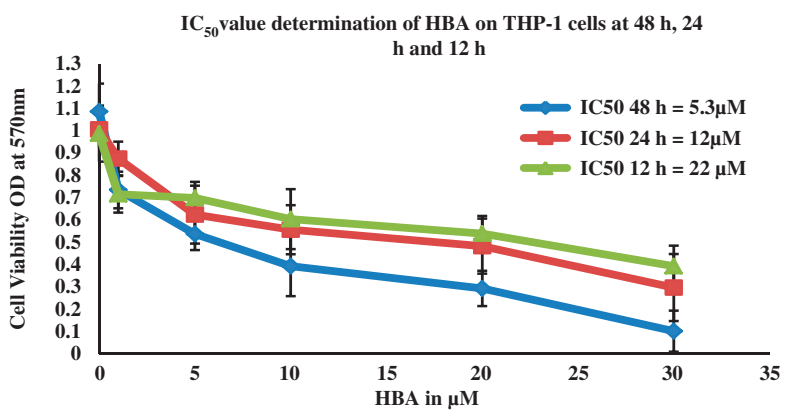

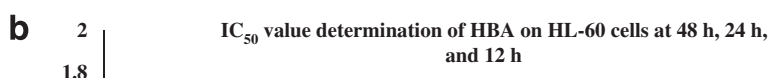

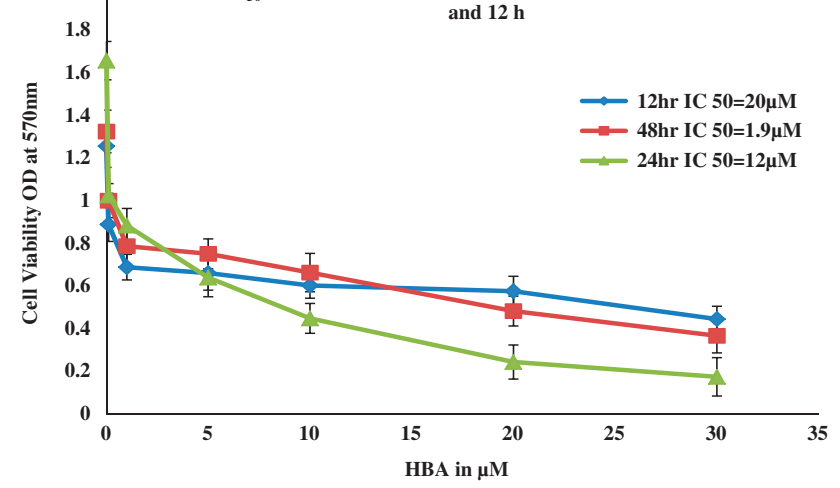

d

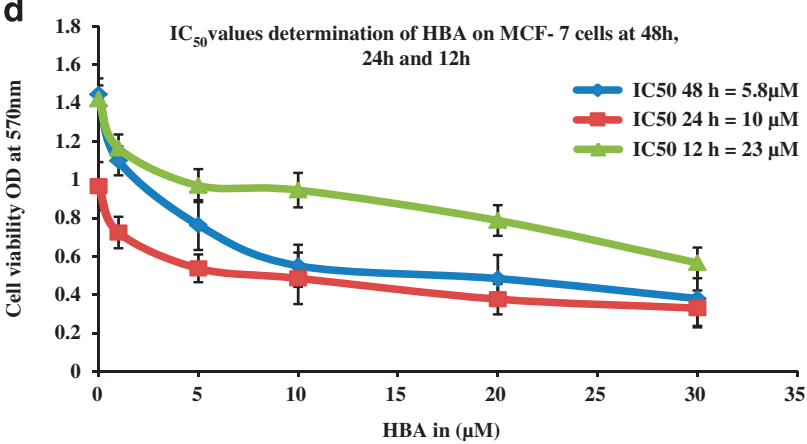

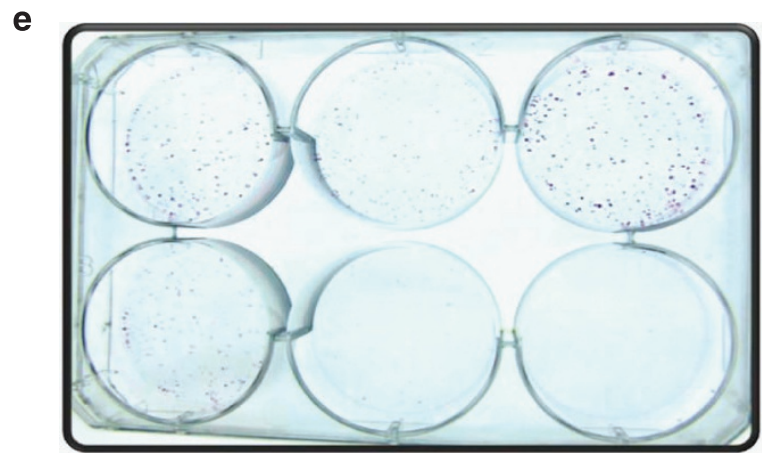

Figure 1 (a-e) Effect of HBA on proliferation of human leukemia cell lines (HL-60 and THP-1) and breast cancer cell line MCF-7. HL-60, THP-1 and MCF-7 cells (15 $\times 10^{3}$ ) were seeded in 96-well plate. HBA and CBA were added to the cells at different concentrations, whereas the untreated control received the vehicle only. MTT dye was added and OD was measured as described in the Materials and Methods. Data are Mean \pm S.D. $(n=6$ wells) and representative of two similar experiments. (e) In vitro clonogenic assay performed on MCF-7 cells. Cells were seeded in six-well plates. After $24 \mathrm{~h}$, the cells were treated with the indicated concentrations of HBA for $24 \mathrm{~h}$. After the completion of the treatment, the plates were placed in an incubator for a time equivalent to at least six potential cell divisions (to give colonies of $>50$ cells). After fixation, the cells were stained with $0.5 \%$ crystal violet for 30 min and allowed to dry at room temperature

caused significant decrease in the expression of cyclin A protein (Figure 3a). Also in THP-1 cells highly significant decrease in the expression of cyclin $A$ has been observed. However, BA when compared with the untreated control caused marginal change in the expression of cyclin A (Figure 3b). In MCF-7 breast cancer cell line, treatment of cells with $\mathrm{HBA}$ caused significant inhibition in the expression of cyclin A protein when compared with the untreated MCF-7 cells (Figure $3 \mathrm{c}$ ). Thus, in the present study, HBA decreased the levels of cyclins D, E and A in a concentration-dependent manner, indicating that treatment with HBA leads to an inhibition of PI3K activity, followed by reduced activation of AKT, which then influences downstream cell cycle regulators that are directly or indirectly regulated by activated AKT.
Upregulation of p21 and p27 and inhibition of pGSK3 $\beta$ induced cell cycle arrest in HL-60, THP-1 and MCF-7 cells. GSK3 $\beta$ is a substrate of PI3K/AKT pathway that is constitutively active in unstimulated cells. ${ }^{13}$ Keeping in view the importance of GSK3 $\beta$ in regulation of cyclins, CDKis and thus on the cell cycle, we sought to examine the phosphorylated levels of GSK3 $\beta$. We have found significant inhibition of pGSK3 $\beta$ in HBA-treated HL-60 cells in a dose-dependent manner (Figure 4a). In THP-1 cells, the inhibition in the pGSK3 $\beta$ expression was observed at slightly higher concentrations. Under similar conditions, THP-1 cells treated with BA could produce only marginal effect at higher concentration of $30 \mu \mathrm{M}$ (Figure 4b). Looking into the expression profile of pGSK3 $\beta$ in MCF-7 cells, we found that HBA could inhibit this 

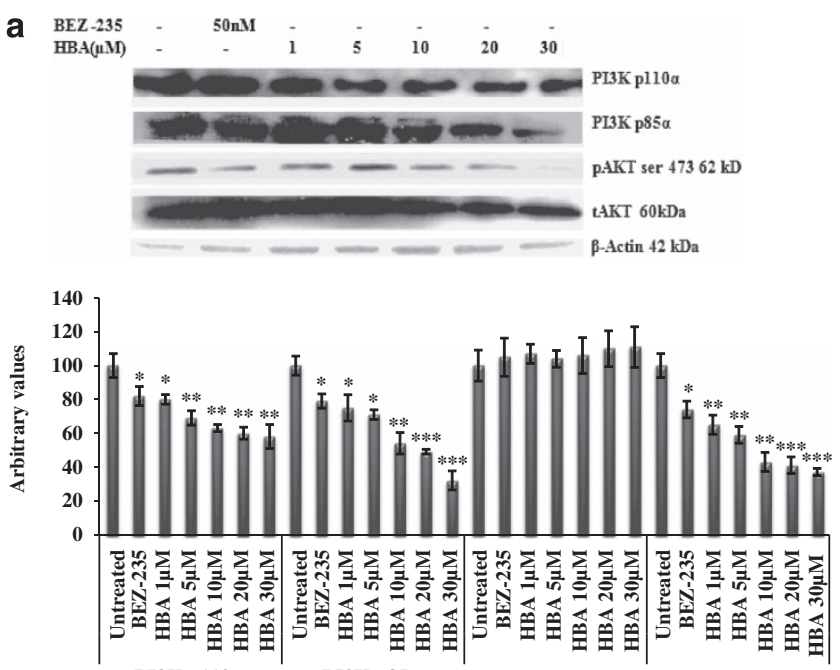

PI3K p110。
tAKT

pAKT

C
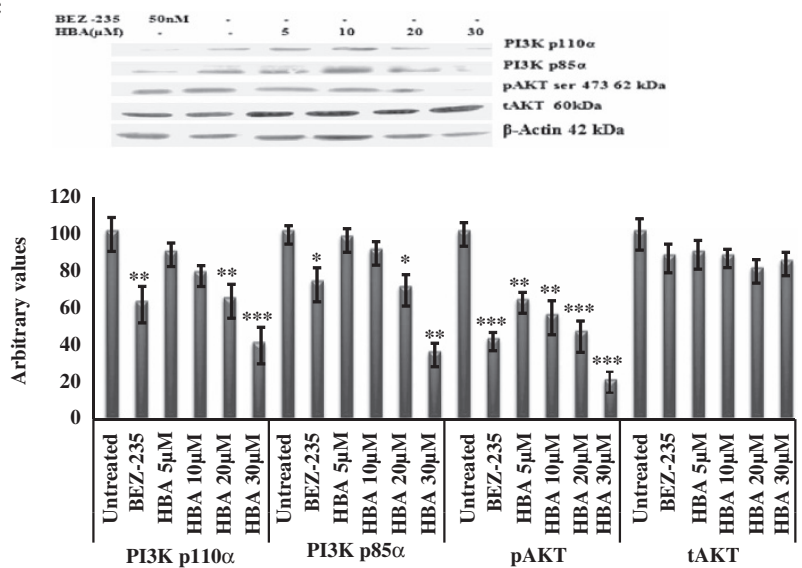

b
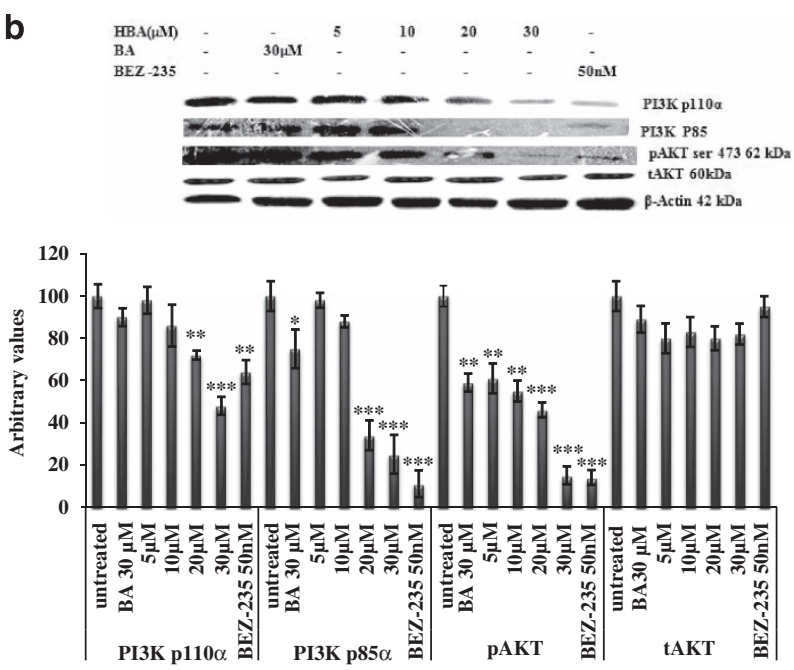

d $\mathbf{B A}(\mu \mathrm{M})$

70

so

30

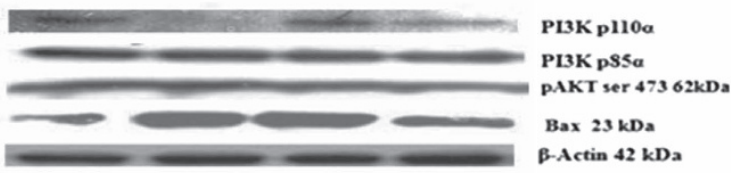

e $\mathbf{B A}(\mu \mathrm{M}) \quad \mathbf{1 0 0} \quad 70 \quad 50$

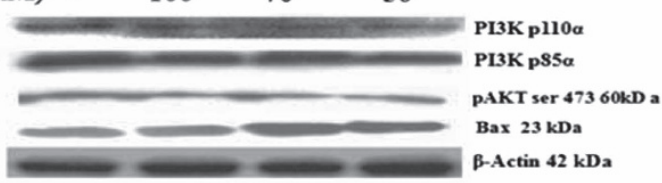

Figure 2 (a-e) Immunoblot analysis for the expression PI3K p110 $\alpha$ and p85 in HBA-treated HL-60, THP-1 and MCF-7 cells. Whole-cell lysate was prepared, and protein $(100 \mu \mathrm{g})$ was resolved on $12 \%$ SDS-PAGE gel for western blottig analysis as described in Materials and Methods. Cells $\left(2 \times 10^{6}\right)$ were treated with the indicated concentrations of HBA and BA for $24 \mathrm{~h}$ time periods and analyzed by using specific antibodies. Equal protein loading was confirmed by striping and reprobing the same PVDF membrane with antibody against $\beta$-actin protein. Data are representative of one of two similar experiments. ${ }^{* * \star} P<0.001,{ }^{* \star} P<0.01,{ }^{*} P<0.05$ versus control using Student's $t$-test

protein in a much similar manner to that observed in THP-1 cells (Figure 4c). The pGSK3 $\beta$ expression was also confirmed using fluorescence microscopy in MCF-7 breast cancer cells. The results clearly showed that in untreated cells pGSK $3 \beta$ is highly expressed in the cytoplasm after analyzing with nuclear counter stain DAPI (Figure 4d). Interestingly, HBA treatment induced a gradual decrease in the expression of pGSK3 $\beta$. This inhibition of $p G S K 3 \beta$ in response to HBA treatment coincides with its decreased phosphorylation that was observed through western blotting studies. As we have found inhibition in the expression of cyclins by treatment with HBA in all the three cancer cell lines, we wanted to study whether the treatment of HBA will affect the expression of any of the CDKis, and we observed that HBA treatment to the cancer cells of different histogenic origin caused drastic upregulation in the expression of p21 and p27 cip/kip proteins in a concentration-dependent manner (Figures $4 \mathrm{a}-\mathrm{c}$ ). BA the parent molecule also caused significant p21 and p27 protein upregulation at $30 \mu \mathrm{M}$ concentration in THP-1 cells (Figure 4b). Thus inhibition in the expression of cyclins was caused due to the upregulation in the expression $\mathrm{p} 21 / \mathrm{p} 27 \mathrm{cip} / \mathrm{kip}$ proteins that occurred due to inhibition in the phosphorylation of pAKT and thus inhibition in the downstream effector pathways. These observations provide strong evidence that inhibition of PI3K pathway by HBA in leukemia and breast cancer cells involve regulation of cell cycle by regulating cyclins and CDKis that induce cancer cell death.

HBA induces cell cycle arrest and apoptosis in HL-60 cells, THP-1 and MCF-7 cells. Treatment of HL-60, THP-1and MCF-7 with HBA induced alterations in cell cycle phase distribution and DNA content. We observed changes in cell cycle distribution after $24 \mathrm{~h}$ treatment with various concentrations of HBA. The sub-G $\mathrm{G}_{0}$ fraction was $<6 \%$ in untreated control cells, which increased upto 57.7, 40.5 and $59 \%$ after treatment of the cells with $30 \mu \mathrm{M}$ concentration of HBA in HL-60, THP-1 and MCF-7 cells, respectively (Figures $4 \mathrm{e}-\mathrm{g})$. In THP-1 cells at $5 \mu \mathrm{M}$ concentration, we found $8.3 \%$ increase in the population of $G_{0} / G_{1}$ cells. This suggested that HBA might inhibit cell proliferation by inducing cell $G_{0} / G_{1}$ arrest, followed by apoptosis in THP-1 cells as was also 


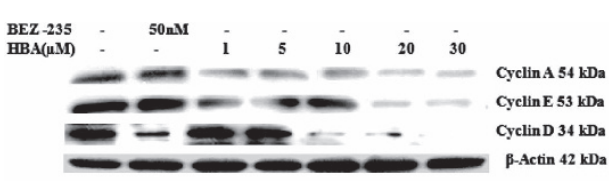

$\left.\begin{array}{r}120 \\ 100 \\ 80 \\ 60 \\ 40 \\ 20\end{array}\right]$ b
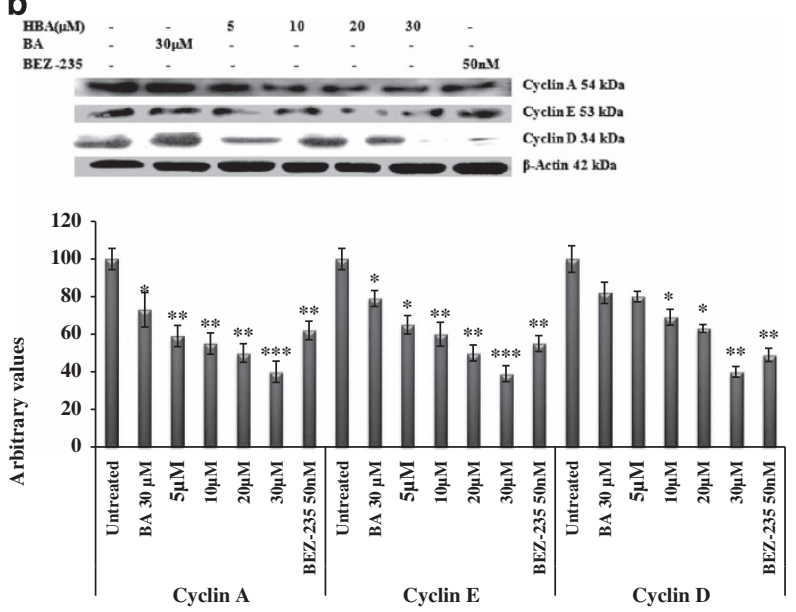

\section{C}
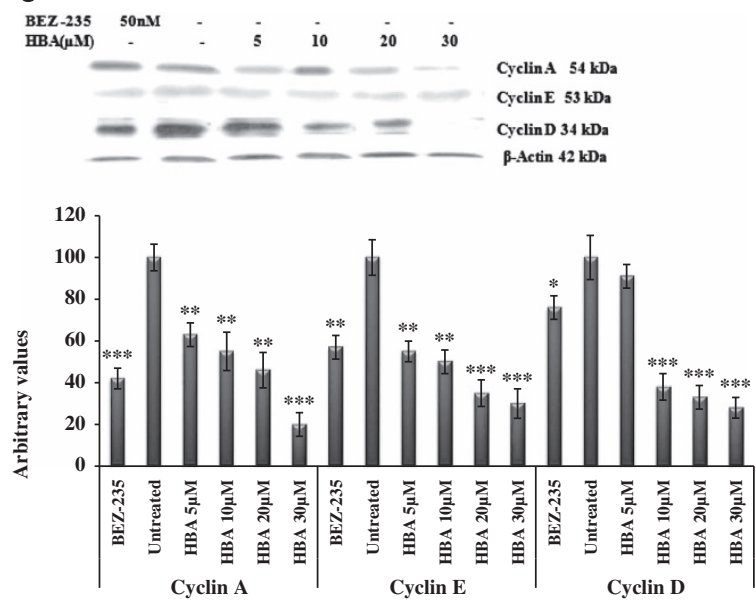

Figure 3 (a-c) Influence of HBA on the expression of proteins involved in cell cycle regulation. HL-60, THP-1 and MCF-7 cells were treated with the indicated concentrations of HBA for $24 \mathrm{~h}$. $\beta$-Actin was used as an internal control to represent the same amount of proteins applied for SDS-PAGE. Specific antibodies were used for the detection of cyclins $A, D$ and $E$ levels. Data are representative of one of two similar experiments. ${ }^{* \star}{ }^{*} P<0.001,{ }^{\star \star} P<0.01,{ }^{*} P<0.05$ versus control using Student's $t$-test

confirmed by protein expression studies of cyclins. Apoptosis in live cells was detected by several other groups using different methods. ${ }^{26-28}$ For confirmation of apoptosis in live cells in our study, we performed annexin V-FITC staining in HBA-treated HL-60 cells and MCF-7. HL-60 and MCF-7 cells were incubated with different concentration of HBA for $24 \mathrm{~h}$, and then cells were stained with annexin V-FITC and PI to assess the apoptotic and necrotic cell populations. As depicted in Figures $4 \mathrm{~h}$ and I, compared with the untreated control early and late apoptotic cell populations has shown concentration-dependent increase upto 3.6 and $50 \%$ in HL-60 cells and upto 0.8 and $35.3 \%$ in MCF-7 at $30 \mu \mathrm{M}$ concentration of $\mathrm{HBA}$, respectively, whereas in untreated control cells the early and late apoptotic cell populations was only 1.8 and $11.6 \%$ in HL-60 cells and 0.9 and $3.2 \%$ in MCF-7 cells.

Modulation in Bcl-2/ Bax expression, generation of reactive oxygen species (ROS) and subsequent mitochondrial membrane potential $\left(\Delta \psi_{\mathrm{m}}\right)$ loss in HL-60, THP-1 and MCF-7 cells. A variety of physiological death signals as well as pathological cellular insults trigger the genetically programmed pathway of apoptosis. ${ }^{29}$ Moreover, PI3K pathway also leads to modulation in the activity of bcl2 family proteins; here we investigated the downstream antiproliferative and the proapoptotic effects of HBA in HL-60, THP-1 and MCF-7 cells by looking into the expression profile of bcl2 family proteins. Proapoptotic protein bax was upregulated after incubation with HBA, whereas the expression levels of antiapoptotic protein bcl2 was downregulated in all the three cancer cell lines (Figures $5 a-c$ ). In the case of THP-1, the expression of bcl2 family proteins got significantly modulated even at $5 \mu \mathrm{M}$ concentration, and the same expression profile was observed in the case of MCF-7 cells treated with HBA. Moreover, to look into the effect of HBA in live cells, MMP loss and ROS generation studies were carried out in HL-60, THP-1 and MCF-7 cells. Treatment of HL-60, THP-1 and MCF-7 cells with HBA caused a disruption of the mitochondrial membrane potential and hyperproduction of ROS as was observed in live HL-60 and MCF-7 cells; however, no ROS production could be observed in THP-1 cells. HBA could lead to mitochondrial membrane permeabilization, which was confirmed by decrease in the cytochrome $c$ expression in the mitochondrial fraction of HL-60 cells (Figure 5a). 
The flow cytometric analysis revealed that HL-60 cells exposed to different concentrations of HBA for $24 \mathrm{~h}$ caused increase in 2',7'-dichlorfluorescein-diacetate (DCFH-DA) fluorescence from $3 \%$ in untreated control to $22 \%$ at $30 \mu \mathrm{M}$ in HL-60 cells; however, in MCF-7 the DCFH-DA fluorescence in untreated control was $5 \%$ that increased upto $36 \%$ at $30 \mu \mathrm{M}$ concentration of HBA (Figures $5 \mathrm{~d}$ and $\mathrm{f}$ ). In addition, THP-1 cells could not generate ROS, and $0.02 \% \mathrm{H}_{2} \mathrm{O}_{2}$ was used as a positive control in the experimental setup that showed upto $40 \%$ ROS generation and the same was upto
$52 \%$ in MCF-7 cells (Figure 5e). Similar to HBA in THP-1 cells treated with $30 \mu \mathrm{M}$ concentration of $\mathrm{BA}$, no ROS generation was observed. Further, rhodamine-123 (Rh-123) retention in mitochondria is driven by $\Delta \psi_{\mathrm{m}}$ that allows the determination of cell population with active integrated mitochondrial functions. In the untreated control cells, almost all cells were bioenergetically active as evidenced by high Rh-123 fluorescence. However, incubation of HL-60, THP-1 and MCF-7 cells with $30 \mu \mathrm{M}$ concentration of HBA caused decrease of $\Delta \psi_{\mathrm{m}}$ upto $41.6,50.7$ and $62 \%$, respectively a
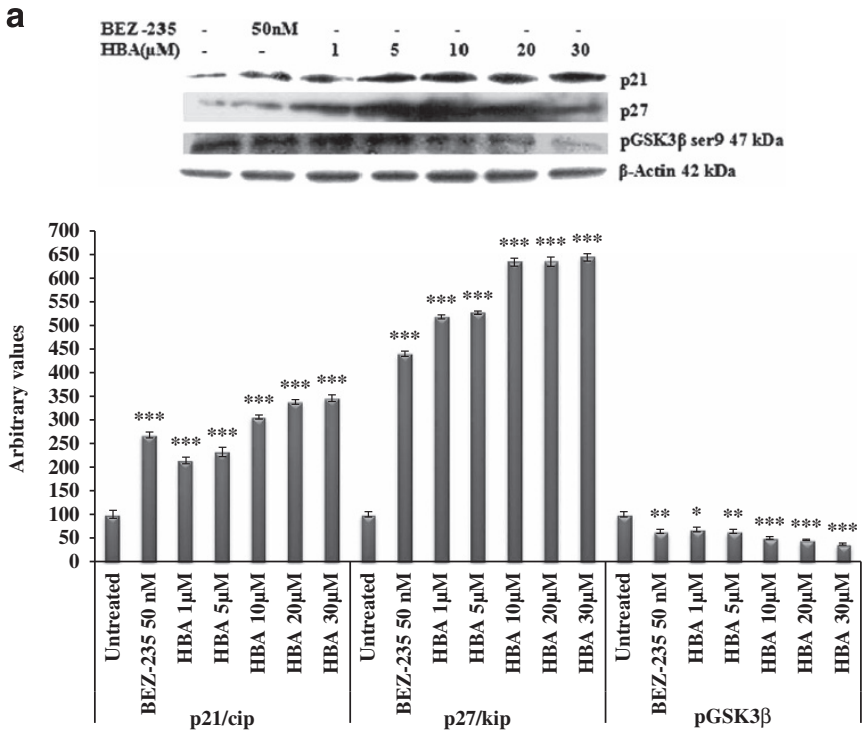

C

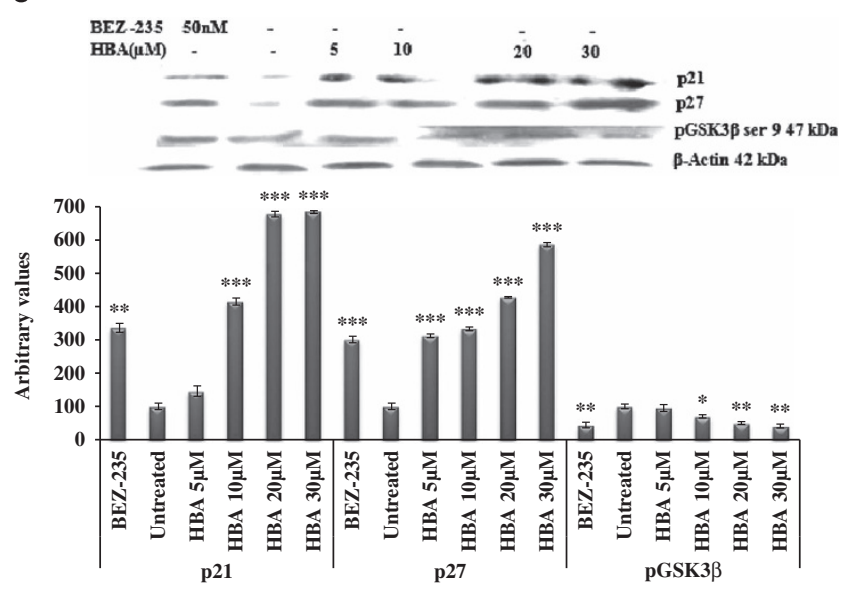

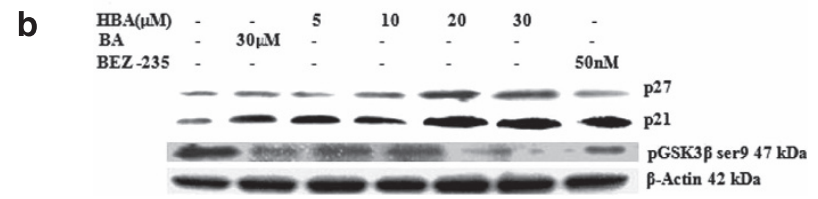

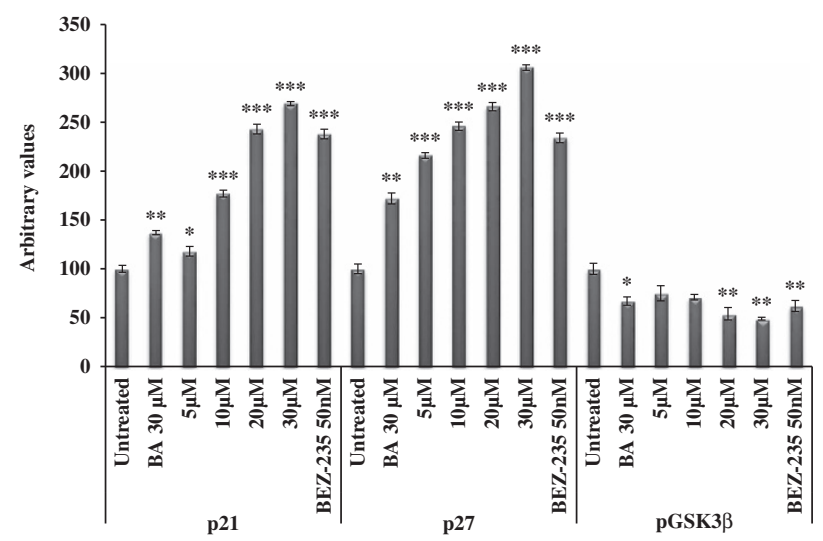

d

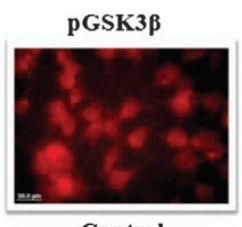

DNA
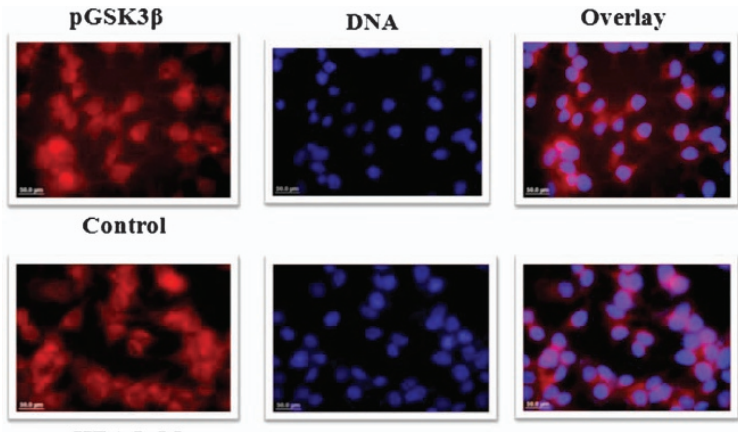

HBA $5 \mu \mathrm{M}$
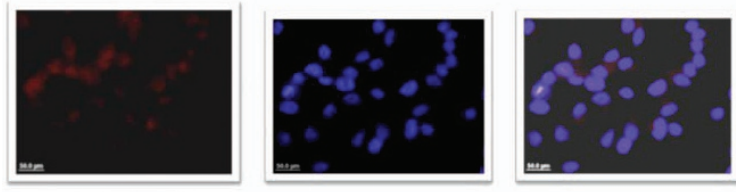

HBA $10 \mu \mathrm{M}$

Figure 4 (a-c) Influence of HBA on the expression of proteins involved in cell cycle regulation. HL-60, THP-1 and MCF-7 cells were treated with the indicated concentrations of HBA for $24 \mathrm{~h}$. $\beta$-actin was used as an internal control to represent the same amount of proteins applied for SDS-PAGE. Specific antibodies were used for the detection of cyclins $A, E$ and $D$ levels. Data are representative of one of two similar experiments. ${ }^{\star * \star} P<0.001,{ }^{\star \star} P<0.01,{ }^{*} P<0.05$ versus control using Student's $t$-test. (d) Confocal immunofluorescence done on MCF-7 cells. Cells were treated with HBA and after completion of the treatment cells were incubated with primary and secondary antibodies. Nuclear staining was done with DAPI. (e-g) Effect of HBA on cell cycle phase distribution. HL-60, THP-1 and MCF-7 cells in culture were treated with the indicated concentrations of HBA for $24 \mathrm{~h}$. Cells were stained with PI to determine DNA fluorescence and cell cycle phase distribution by flow cytometery as described in Materials and Methods. Fraction of cells for hypo diploid (sub-G0, $\leq 2 n$ DNA) population indicative of DNA damage was analyzed from PI versus cell counts shown (\%). Data are representative of one of two similar experiments. ( $h$ and i) Estimation of early and late apoptotic cell population using annexin V-FITC staining. HBA-treated HL-60, THP-1 and MCF-7 cells was analyzed using annexinV-FITC staining. Cells were incubated with the indicated concentrations of HBA for $24 \mathrm{~h}$ and stained with annexin V-FITC and PI to analyze apoptotic and necrotic cell populations as described in Materials and Methods. Data are representative of one of two similar experiments 

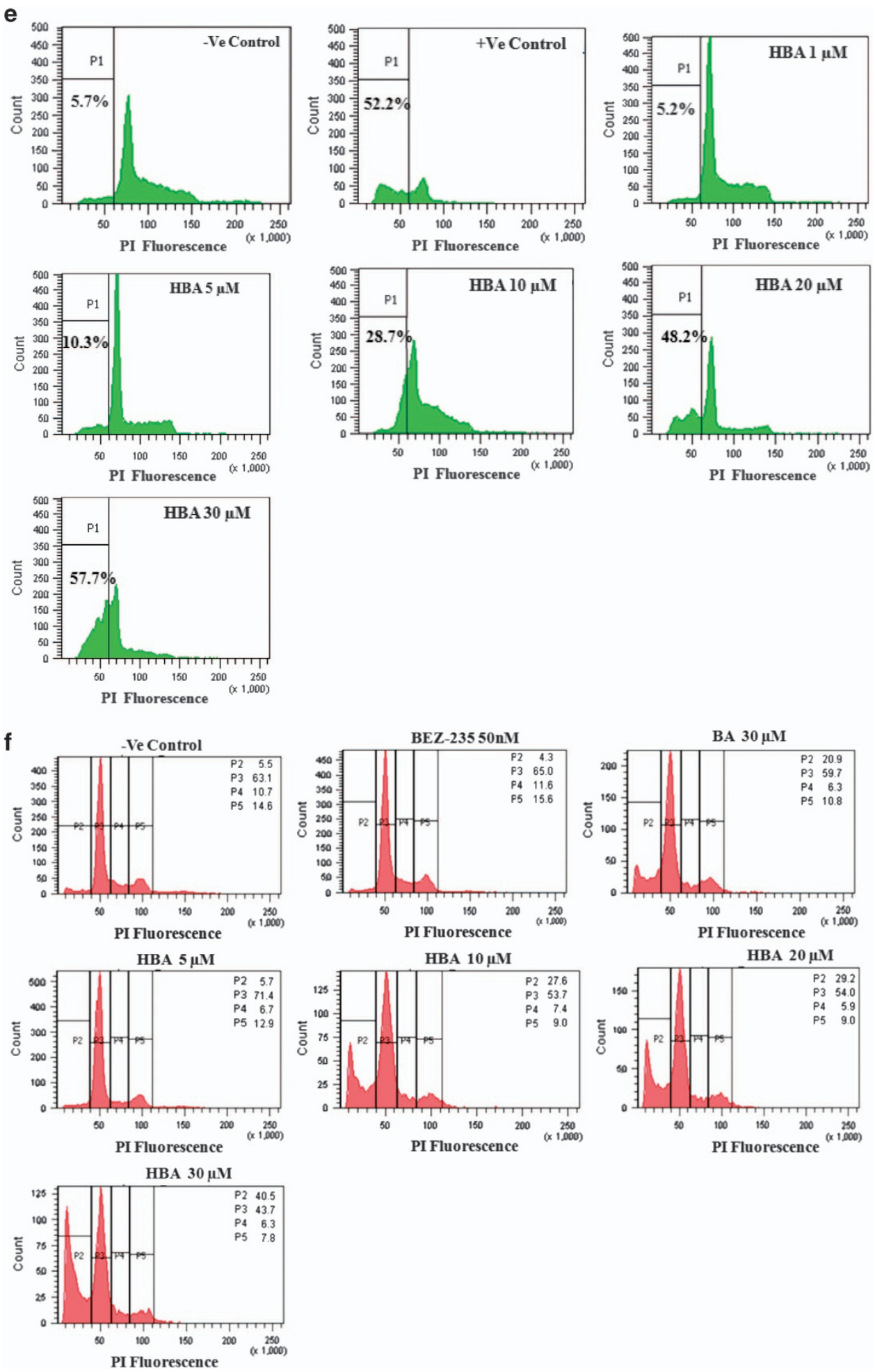

Figure 4 (Continued)

(Figures $5 g-i)$. The loss of mitochondrial potential reflected a direct effect of HBA on mitochondrial function, suggesting that mitochondrial events may be involved in activation of caspases and the simultaneous cell death in HL-60, THP-1 and MCF-7 cells.
Activation of caspases and PARP cleavage in HBAtreated HL-60, THP-1 and MCF-7 cells. Caspases are the members of the cysteine proteases, which are implicated in apoptosis and cytokine processing. HBA caused a strong increase in caspase activity, which peaked at $30 \mu \mathrm{M}$ 


\section{g}
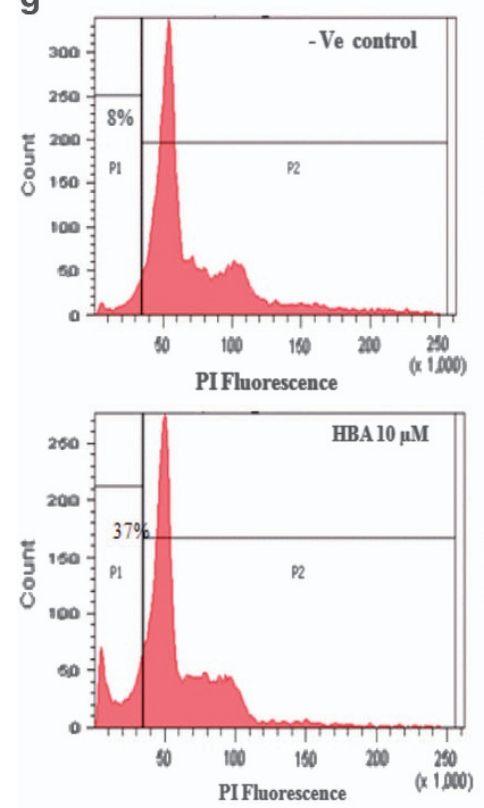

h
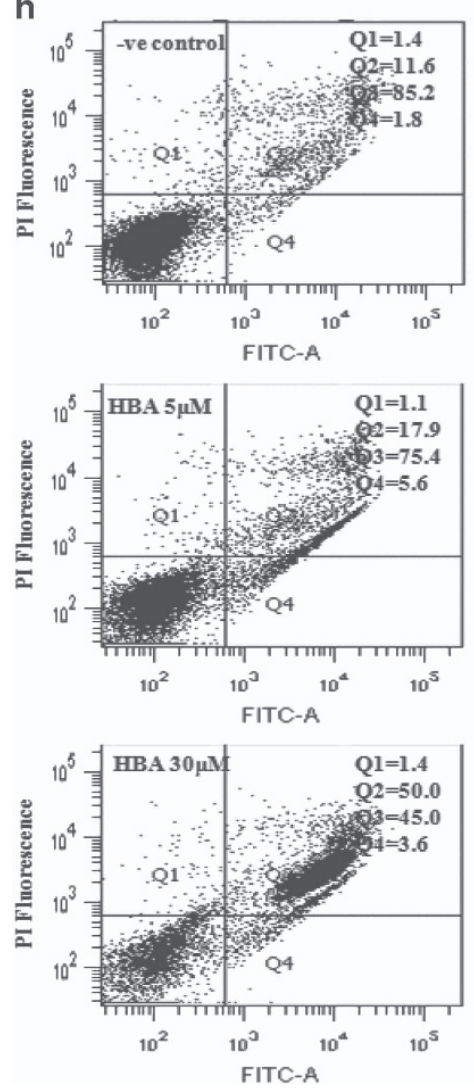
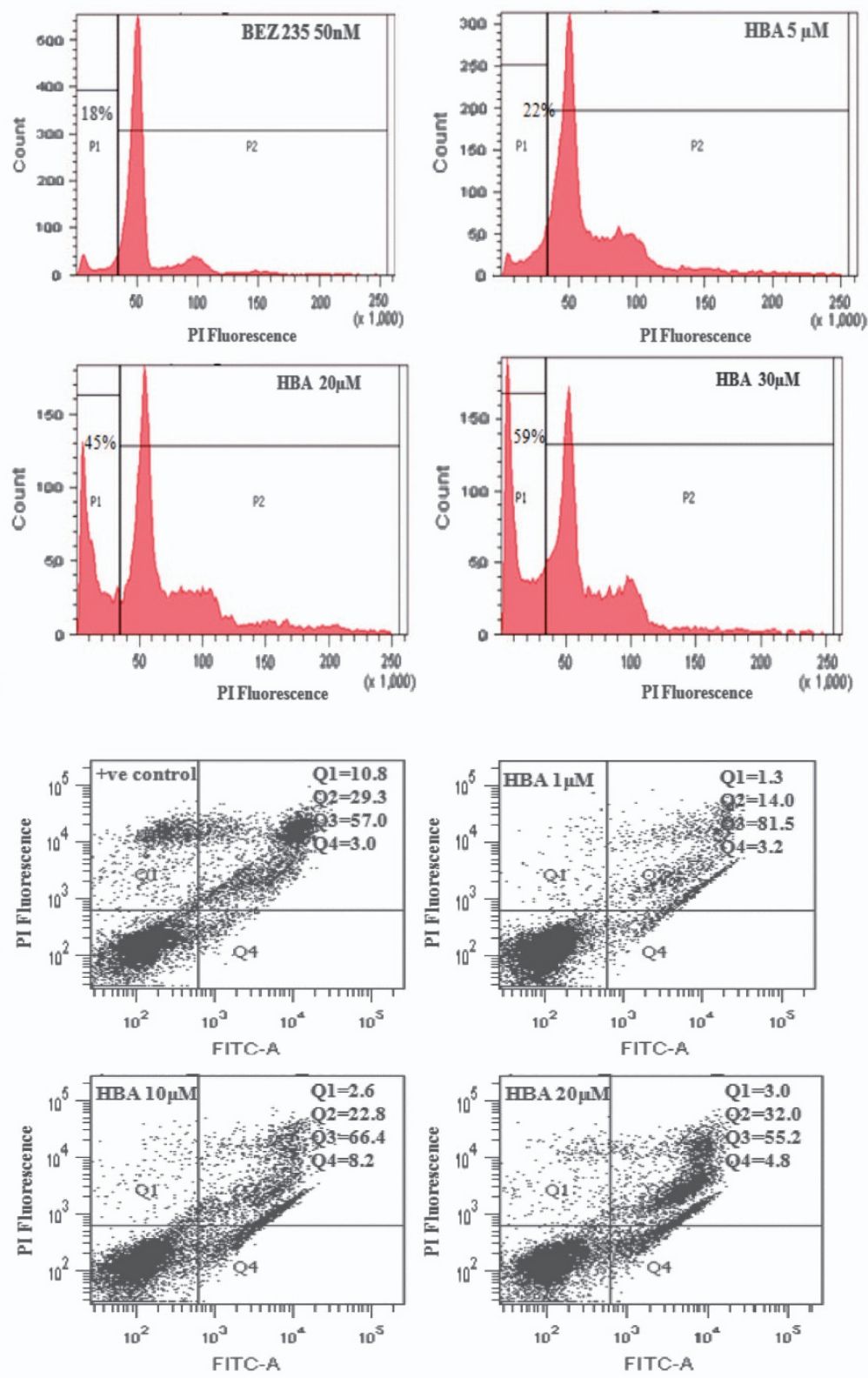

Figure 4 (Continued)

concentration. We observed significant upregulation of active caspase 8 in HL-60, and the similar pattern was observed in THP-1 cells; however, in MCF-7 cells the upregulation pattern was not that significant as was observed in HL-60 and THP-1 cells (Figures $5 \mathrm{a}-\mathrm{c}$ ). In the case of MCF-7 cells, the active caspase 9 upregulation was observed even at $5 \mu \mathrm{M}$ concentration; however, in HL-60 and THP-1 the similar pattern was observer at higher concentrations. We also found significant active caspase 3 upregulation in all the three cancer cell lines. Comparing the upregulation of all the three caspases by BA and HBA, HBA could upregulate the caspase activity several fold higher than $\mathrm{BA}$ as was observed 
i
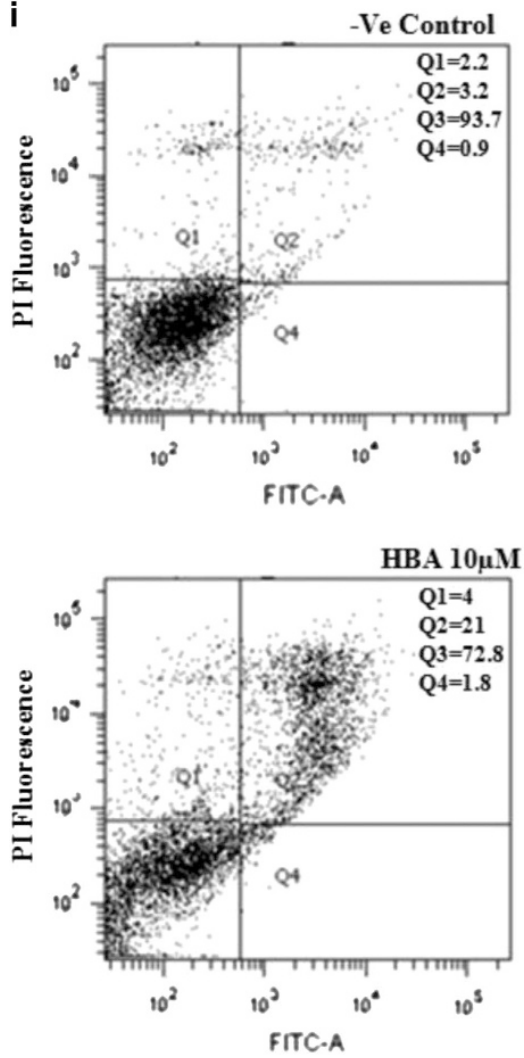
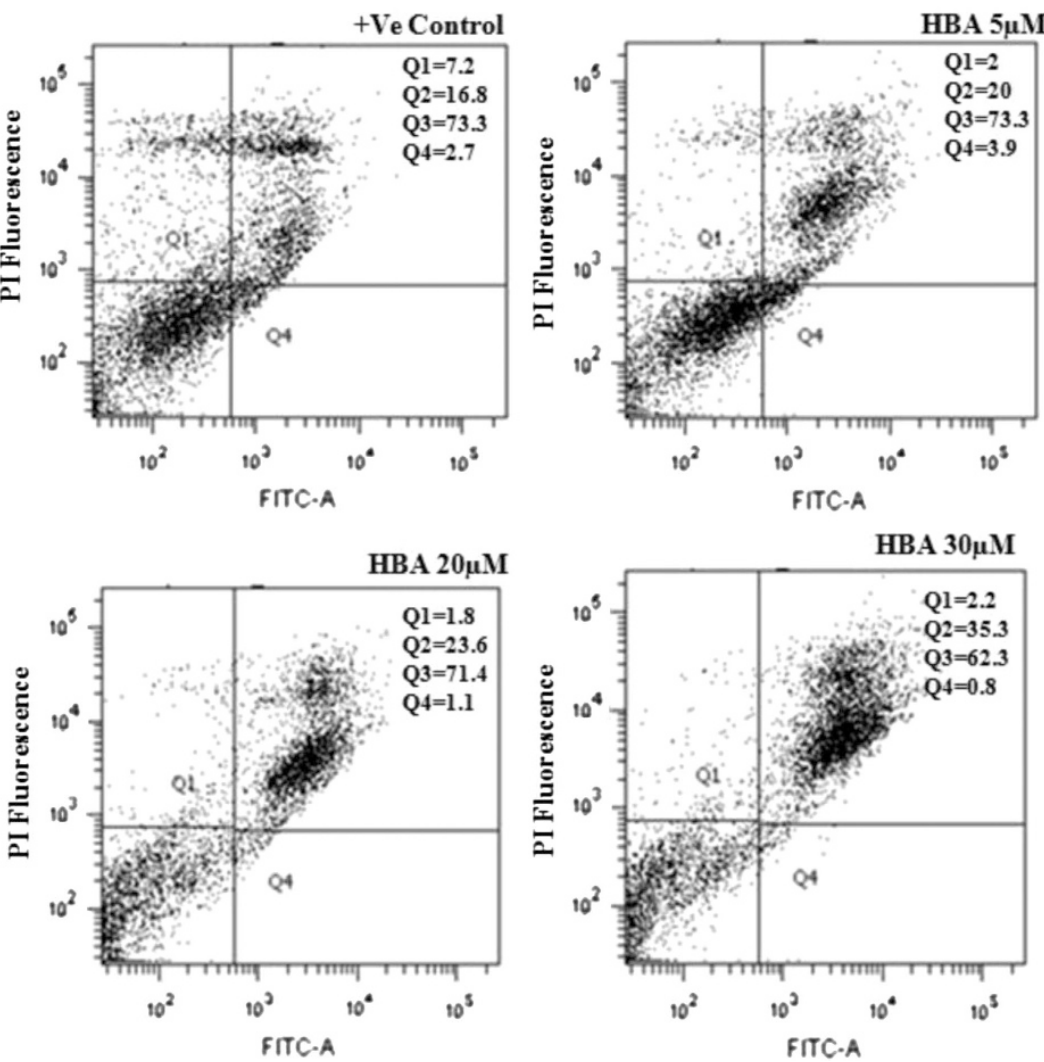

Figure 4 (Continued)

in THP-1 cells. PARP-1 is specifically proteolysed by caspases to a 24-kDa DNA-binding domain and to an $85-\mathrm{kDa}$ catalytic fragment during the execution of the apoptotic program, which essentially inactivates the enzyme by destroying its ability to respond to DNA strand break. In order to further validate the extent of apoptosis induced by HBA; we wanted to see whether PARP has cleaved into its fragments. HL-60 cells were exposed to different concentrations of HBA for $24 \mathrm{~h}$. HBA induced PARP cleavage into 85 and $24 \mathrm{kDa}$ at $5 \mu \mathrm{M}$ concentrations that became more prominent at the 20 and $30 \mu \mathrm{M}$ concentrations (Figure 6a). BEZ-235 used as the positive control induced significant PARP cleavage when used at $50 \mathrm{nM}$ concentration for $24 \mathrm{~h}$.

Inhibition of the NFKB expression. NFKB is a transcription factor that can be induced by a variety of signals. Understanding the significant involvement of $\mathrm{NF}_{K} \mathrm{~B}$ in maintaining the cell survival, we have tried to monitor the effect of HBA on the expression profile of this protein in HL-60, THP-1 and MCF-7 cells. Treatment of HL-60 cells with HBA significantly inhibited the expression of transcriptional factor $\mathrm{NF} K \mathrm{~B}$ and the highest significant inhibition was observed at $30 \mu \mathrm{M}$ concentration. However, in the case of THP-1 and MCF-7, NFKB transcription factor was inhibited even at $10 \mu \mathrm{M}$ concentration of HBA comparing with the parent $\mathrm{BA}$, which was unable to show comparable inhibition at $30 \mu \mathrm{M}$ concentration (Figure 6b). BEZ-235 used as the positive control also showed significant inhibition of $\mathrm{NF} \kappa \mathrm{B}$ protein expression in all the three cancer cell lines at a concentration of $50 \mathrm{nM}$ for $24 \mathrm{~h}$.

Cell migration assay. Tumor invasion and metastasis require, among other cell behaviors, enhanced cancer cell mobility. ${ }^{30}$ In order to assess the effect of the compound on the migratory properties of cancer cells, MCF-7 cell monolayers were wounded by scratching and treated with HBA for $24 \mathrm{~h}$. Cell cultures were photographed, and cell migration was assessed by comparing the gap sizes between the control and the treated wells. In the HBA-treated MCF-7 cells, the number of invasive cells that penetrated the respective wound was inhibited, and cell migration got significantly stopped. However, at higher concentration the cell morphology get altered due to the inhibitory effect of the compound HBA on cell migration and invasion (Figure 6c). Similar effects has also been found in MCF-7 cells. Thus our study has implications for rationale approaches to limiting cancer invasion and metastasis.

Pharmacodynamics and estimation of acute toxicity by BA and HBA. Toxicological studies help to make an important decision about the use of new chemical entity as clinically effective and safe drug. Sub-acute oral toxicity has been advocated as a fundamental test for assessing safety, which has been most often applied previously in many safety assessment studies. ${ }^{31}$ In the development of BA derivative as an antineoplastic agent, we were keen to observe whether $\mathrm{BA}$ or HBA has any toxicity associated with them. It was 
interesting to observe that both BA and HBA did not show any treatment-related toxic manifestations and mortality up to the dose of $2000 \mathrm{mg} / \mathrm{kg}$ as compared with the vehicle control animals. The animals did not show any changes in the general appearance during the observation period. Also no significant change was observed in weekly body weight, feed (Table 1a), water consumption and any of the biochemical (Table 1b) or hematological parameters (Table 1c).

Effect of HBA and BA on Ehrlich solid tumor. In vivo antitumor activity of HBA and BA against EAC (Ehlirch ascetic carcinoma) was evaluated by injecting $10 \times 10^{6} \mathrm{EAC}$ cells intramuscularly in the right thigh of Swiss male mice. As shown in Table 2, on thirteenth day, the tumor growth inhibition was calculated after treatment with HBA and BA on the basis of average tumor weight at a dose of $50 \mathrm{mg} / \mathrm{kg}$ i.p. and $100 \mathrm{mg} / \mathrm{kg}$ i.p. for BA and $40 \mathrm{mg} / \mathrm{kg}$ i.p. for HBA. For BA, the tumor-growth inhibition was found to be upto $39.00 \%$ and $28.05 \%$ at a dose of $100 \mathrm{mg} / \mathrm{kg}$ i.p. and $50 \mathrm{mg} / \mathrm{kg}$ i.p., respectively, as $1031.5 \pm 54.21$ and $1215 \pm 51.8 \mathrm{mg}$ average tumor weights were measured as compared with $1689.95 \pm 88.86 \mathrm{mg}$ of the control group. For HBA, the tumorgrowth inhibition was found to be upto $33.96 \%$ at a dose of $40 \mathrm{mg} / \mathrm{kg}$ i.p., and an average tumor weight was found a

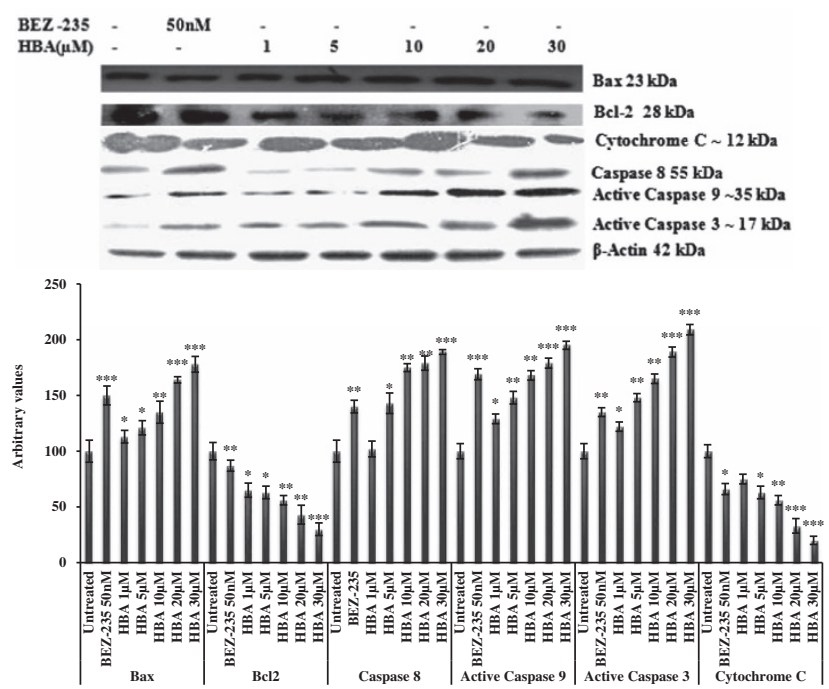

C

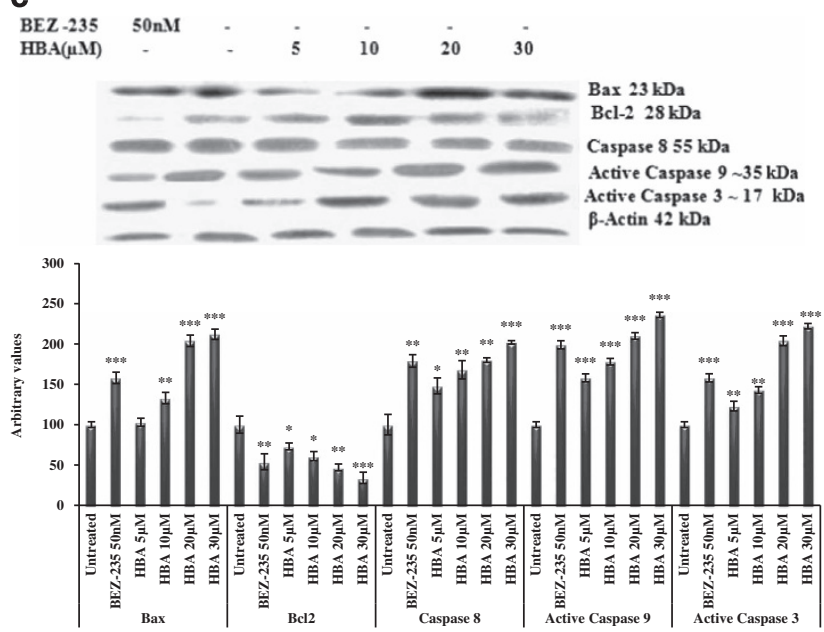

b

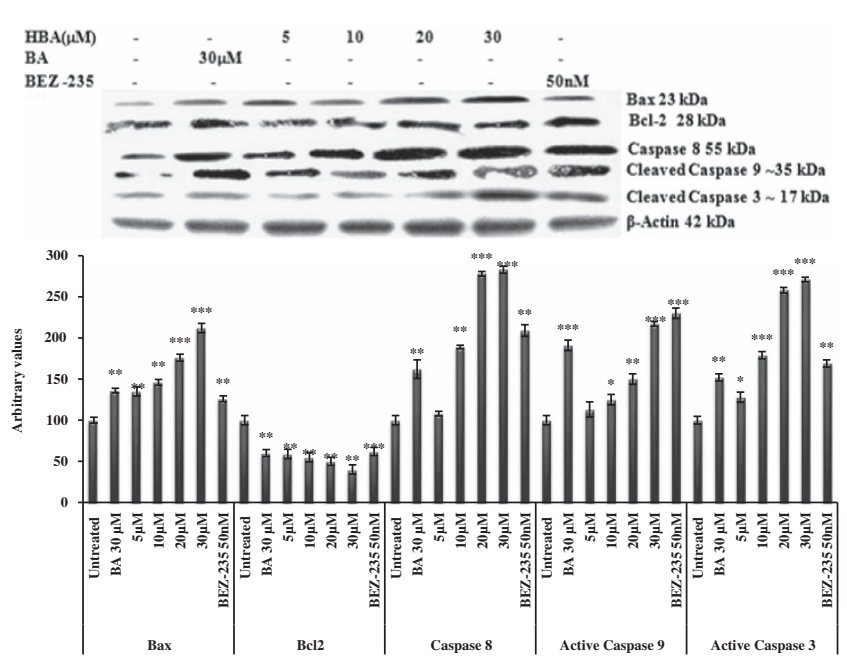

d
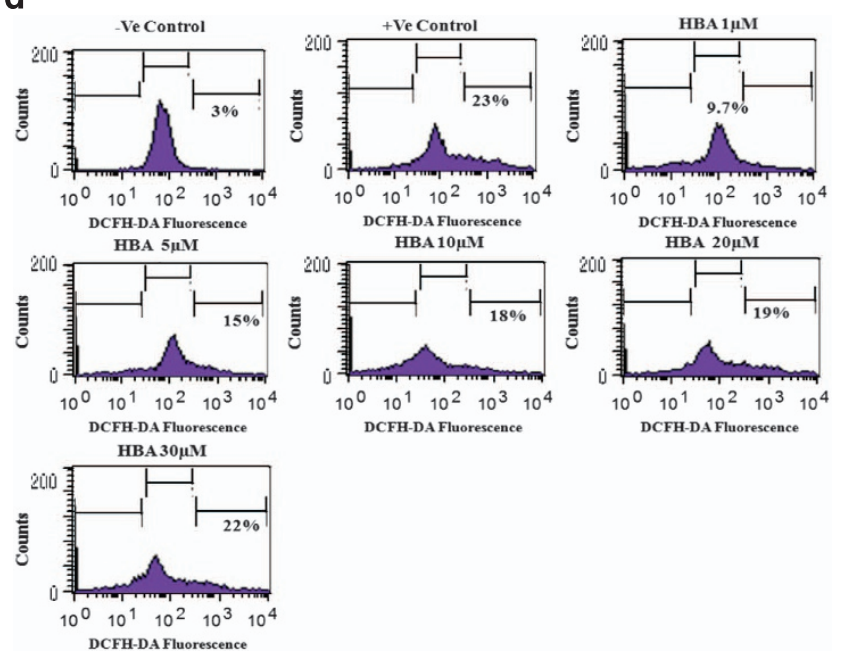

Figure 5 (a-c) Influence of HBA on the expression of proapoptotic and antiapoptotic proteins. HL-60, THP-1 and MCF-7 cells were treated with HBA, and the whole-cell lysate were prepared as described in Materials and Methods to observe the bcl-2/bax and cytochrome $c$ expression. HBA induced activation of caspases in HL-60 cells, THP-1 and MCF-7 cells. Whole-cell lysate were prepared using HL-60 cells $(2 \times 106)$ treated with different concentrations of HBA for the indicated time periods, and $100 \mu \mathrm{g} / \mathrm{ml}$ of protein were subjected to immunoblotting. Specific caspases 8 and 9 and caspase 3 antibodies was used for detection. Reprobing of the same membrane with the antibody against $\beta$-actin did not showed any change in the expression of this protein. Data are representative of one of two similar experiments. (d-f) HBA mediated early generation of ROS in HL-60, THP-1 and MCF-7 cells. Cells treated with the indicated concentrations of HBA for $24 \mathrm{~h}$, followed by incubation with DCFH-DA (5 $\mu \mathrm{M})$ for $30 \mathrm{~min}$. Cells were analyzed for DCF-fluorescence on flow cytometer in the FITC (DCF-HAD Fluorescence) versus count channels. Data are representative of one of two similar experiments. (b, $\mathbf{g}$-i) HBA induced mitochondrial membrane potential loss $(\Delta \Psi \mathrm{m})$ in HL-60, THP-1 and MCF-7 cells. Cells were incubated with HBA at different concentrations in 6-well plate for $24 \mathrm{~h}$. Cells were stained with Rodamine-123 $(2 \mu \mathrm{M})$ and analyzed on flow cytometer in the FITC (Rh-123 fluorescence) versus count channels. Data are representative of one of two similar experiments 

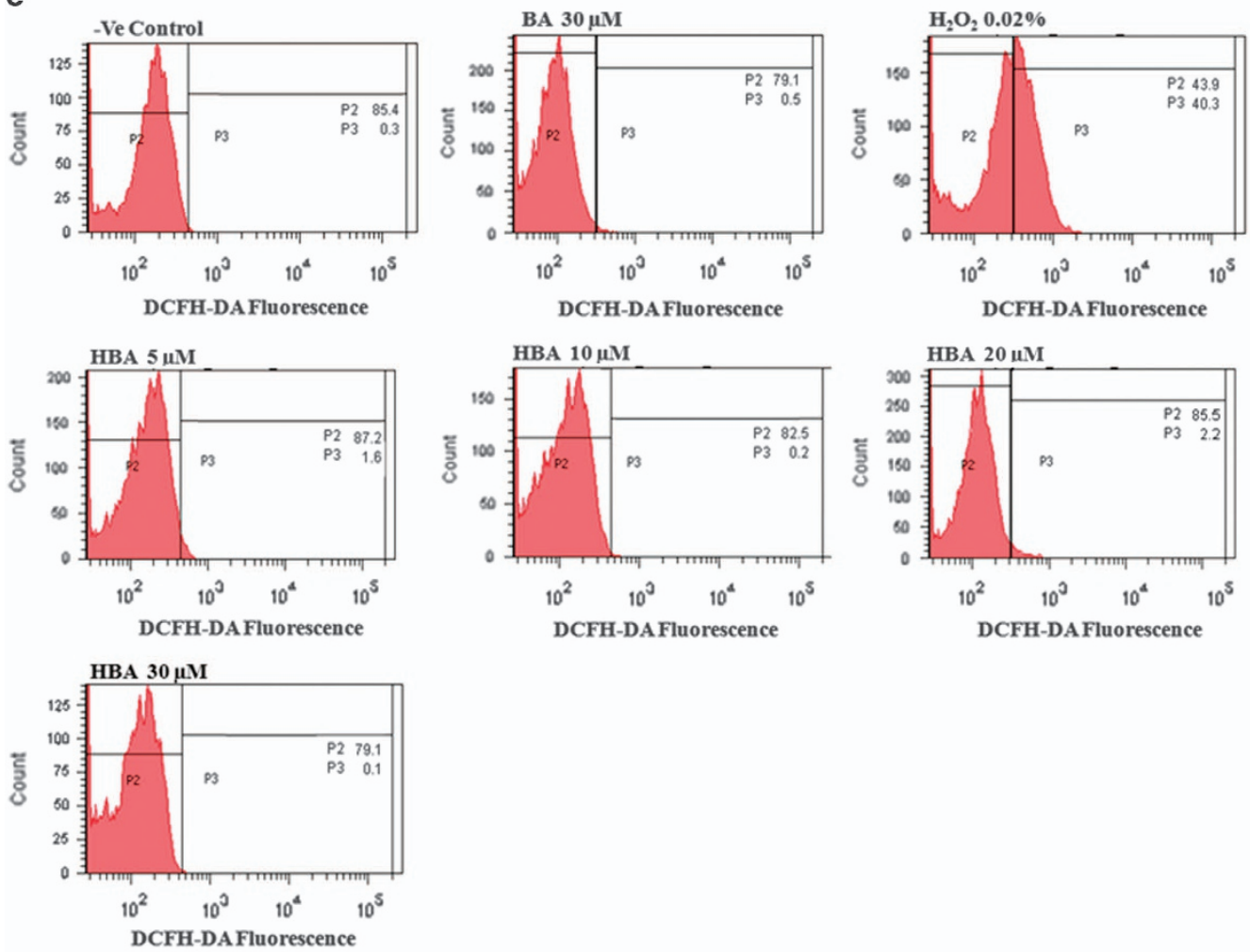

f
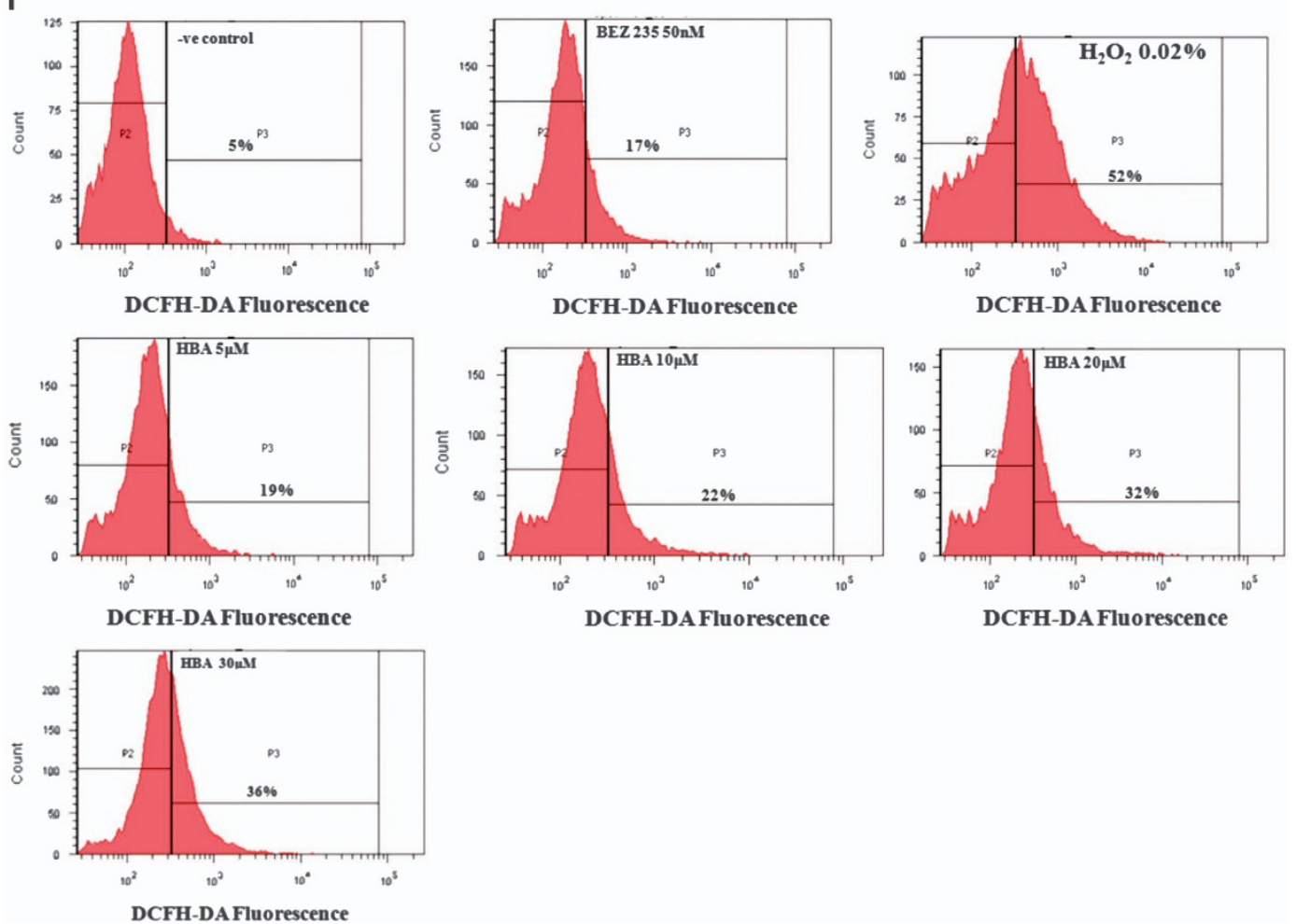

Figure 5 (Continued) 


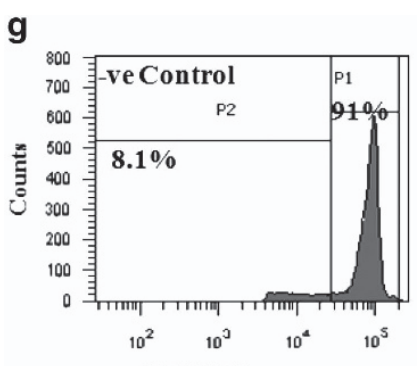

Rh-123 Fluorescence

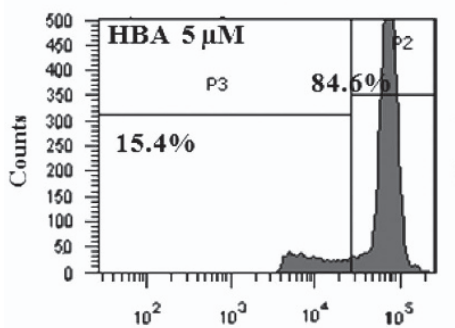

Rh-123 Fluorescence

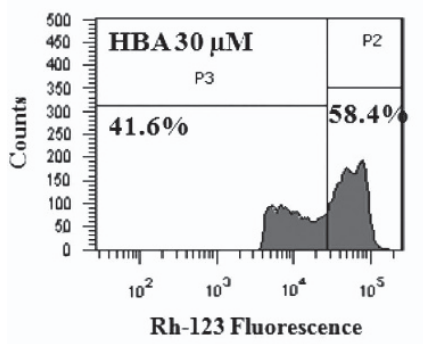

n

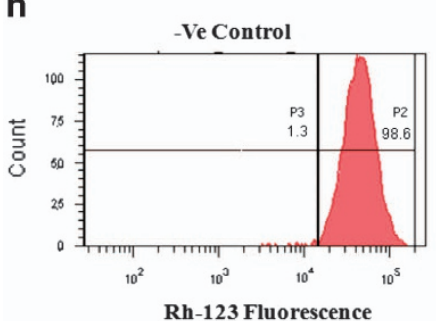

Rh-123 Fluorescence

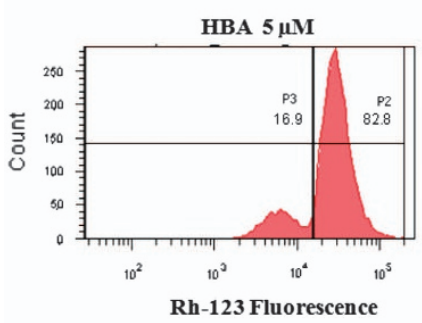

HBA $30 \mu \mathrm{M}$

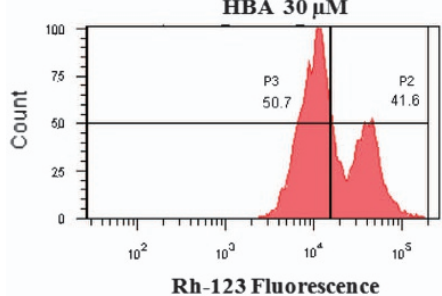

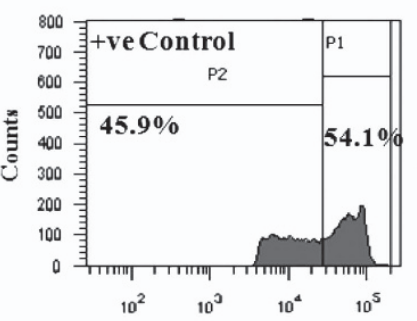

Rh-123 Fluorescence

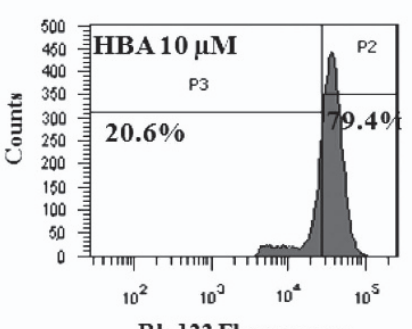

Rh-123 Fluorescence

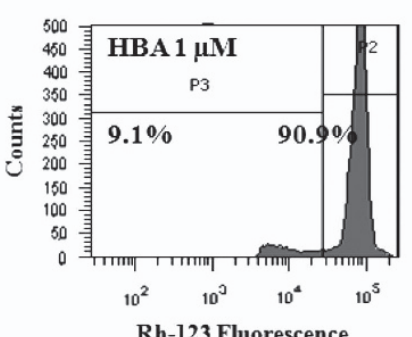

Rh-123 Fluorescence

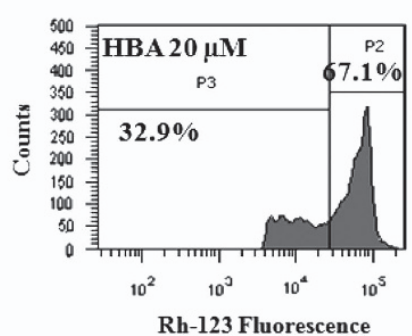

Rh-123 Fluorescence
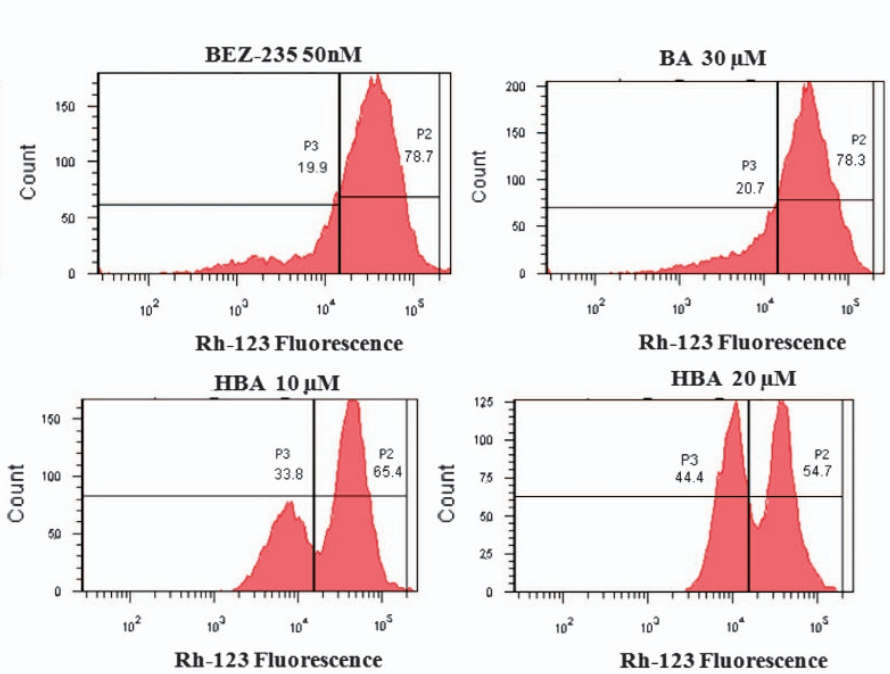

Rh-123 Fluorescence

Figure 5 (Continued) 


\section{i}

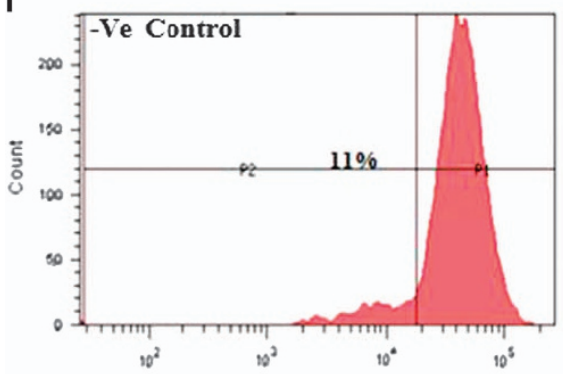

Rh-123 Fluorescence

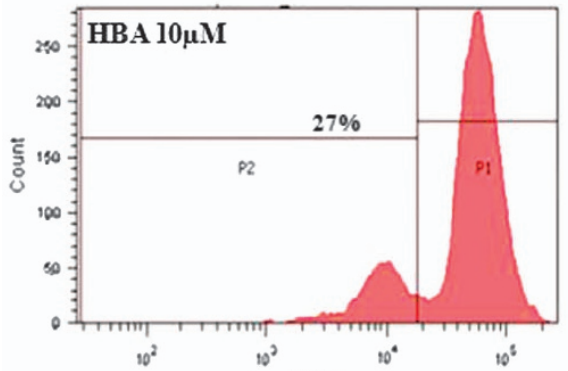

Rh-123 Fluorescence

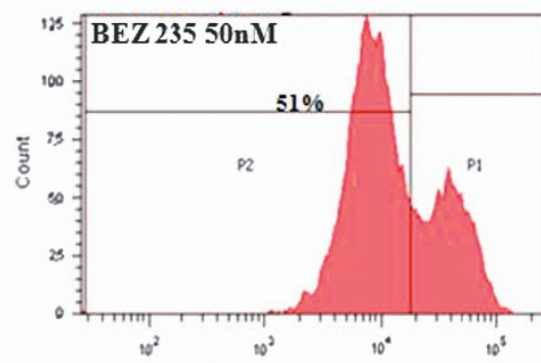

Rh-123 Fluorescence

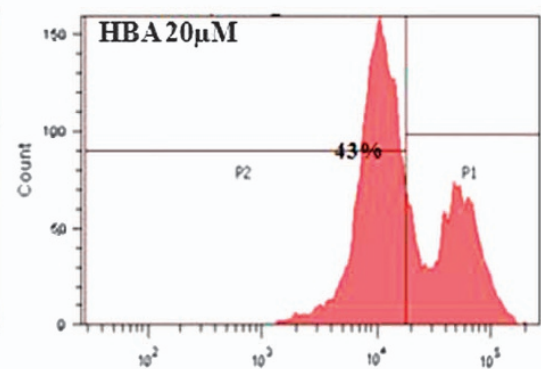

Rh-123 Fluorescence

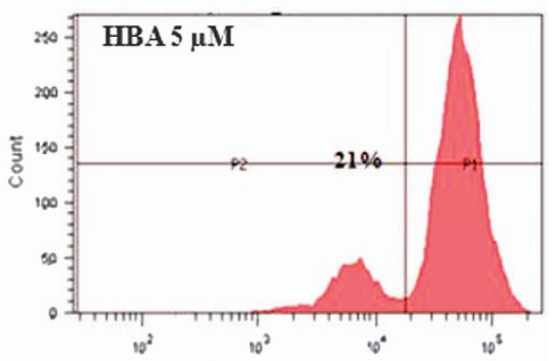

Rh-123 Fluorescence

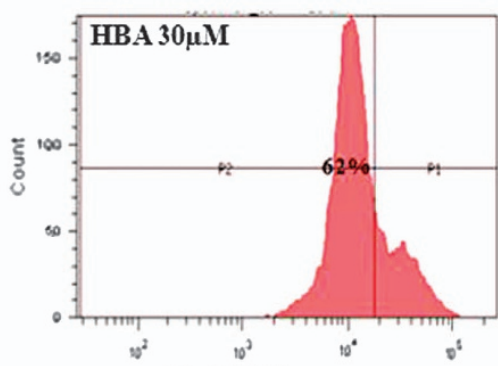

Rh-123 Fluorescence

Figure 5 (Continued)

a

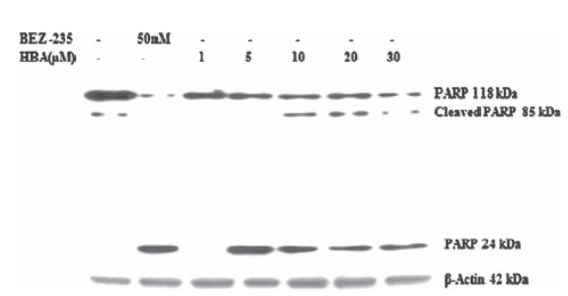

b

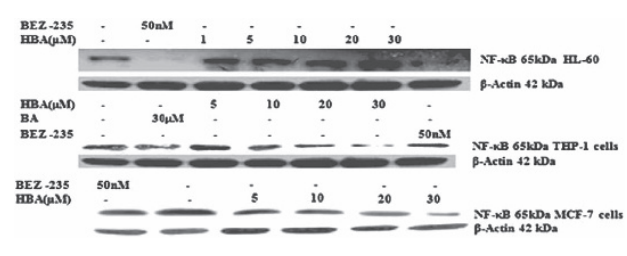

C
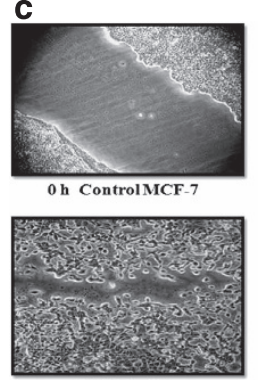

HBA $5 \mu \mathrm{M}$

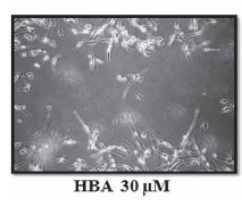

NFKB expression in HL-60 cells
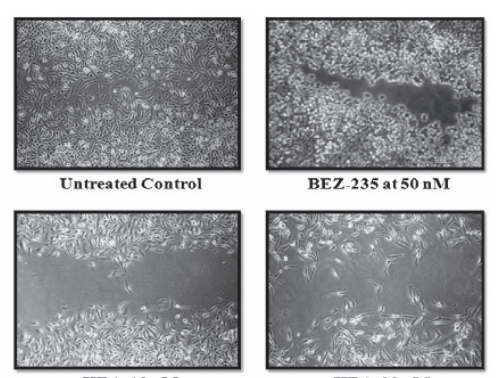

HBA $10 \mu M$
BEZ-235 at $50 \mathrm{nM}$

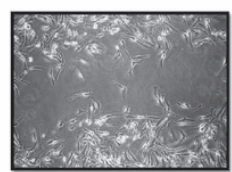

Figure 6 (a) Influence of HBA on the extent of PARP cleavage and apoptosis. Whole-cell lysate were prepared using $\mathrm{HL}-60$ cells $\left(2 \times 10^{6}\right)$ treated with different concentrations of HBA for the indicated time periods, and $100 \mu \mathrm{g} / \mathrm{ml}$ of protein were subjected to immunoblotting. (b) Influence of HBA on the expression of transcription factor NF- $\kappa$ B. Whole-cell lysate were prepared using HL-60 cells, THP-1 and MCF-7 cells $\left(2 \times 10^{6}\right)$ treated with different concentrations of HBA for the indicated time periods, and $100 \mu \mathrm{g} / \mathrm{ml}$ of protein were subjected to immunoblotting. Specific $\mathrm{NF}_{\kappa} \mathrm{B}$ antibody was used for the detection of $\mathrm{NF}_{\kappa} \mathrm{B}$. Reprobing of the some membrane with the antibody against $\beta$-actin did not show any change in the expression of this protein. Data are representative of one of two similar experiments. ${ }^{* \star \star} P<0.001,{ }^{* \star} P<0.01,{ }^{*} P<0.05$ versus control using the Student's $t$-test. (c) In vitro cell migration assay on MCF-7 cells. Briefly cells were seeded in six-well plate. When a tight cell monolayer was formed, a wound was created using a 1000- $\mu$ l tip, and the cell was then washed three times with PBS to remove cell debris. Cells were then treated with the indicated concentrations of HBA. After the completion of the treatment, fresh medium was added to the cells. The number of cells that migrated toward the wound was visualized using $\times 10$ objective Olympus 
Table 1a Mean weekly feed and water consumed by female mice during the acute oral toxicity study of BA and HBA

\begin{tabular}{lcc}
\hline Treatment & First week & Second week \\
\hline Weekly feed consumed $(g)$ & \\
Control & $37.54 \pm 1.78$ & $39.04 \pm 2.5$ \\
BA & $39.14 \pm 5.3$ & $43.98 \pm 7.04$ \\
HBA & $38.58 \pm 2.85$ & $42.88 \pm 3.87$ \\
Weekly water consumed $(m l)$ & \\
Control & $47.18 \pm 5.54$ & $49.28 \pm 7.91$ \\
BA & $46.66 \pm 7.04$ & $50.65 \pm 8.84$ \\
HBA & $46.7 \pm 5.51$ & $50.05 \pm 9.43$ \\
\hline
\end{tabular}

Values are represented as mean \pm S.E.M. ( $n=7 /$ group). Student-NewmanKeul's test and T-test (ANOVA)

Table 1b Mean values of various biochemical parameters measured from serum of female mice treated with vehicle, BA and HBA (single oral dose)

\begin{tabular}{lccr}
\hline Parameters & Control & BA & \multicolumn{1}{c}{ HBA } \\
\hline Glucose $(\mathrm{mg} / \mathrm{dl})$ & $156.3 \pm 26.88$ & $159.2 \pm 10.03$ & $155.7 \pm 18.77$ \\
Triglyceride $(\mathrm{mg} / \mathrm{dl})$ & $127.5 \pm 20.77$ & $144 \pm 26.45$ & $151.2 \pm 33.68$ \\
Cholesterol (mg/dl) & $86.14 \pm 31.09$ & $76.73 \pm 12.03$ & $83.76 \pm 11.13$ \\
SGOT (IU/l) & $141.45 \pm 7.22$ & $147.93 \pm 19.31$ & $121.085 \pm 24.21$ \\
Total Protein (g/dl) & $4.67 \pm 0.91$ & $6.83 \pm 0.48$ & $5.16 \pm 0.08$ \\
Creatinine (mg/dl) & $0.53 \pm 0.05$ & $0.57 \pm 0.06$ & $0.483 \pm 0.09$ \\
Urea (mg/dl) & $36.09 \pm 3.98$ & $36.47 \pm 1.12$ & $37.16 \pm 1.33$ \\
Bilirubin (mg/dl) & $0.654 \pm 0.01$ & $0.518 \pm 0.01$ & $0.53 \pm 0.05$ \\
ALP (IU/l) & $152.4 \pm 10.83$ & $157.7 \pm 14.11$ & $167.44 \pm 3.71$
\end{tabular}

Values are represented as mean \pm S.E.M. ( $n=7 /$ group). Student-NewmanKeul's test and T-test (ANOVA)

Table 1c Mean values of various hematological parameters measured from whole blood of female mice treated with BA and HBA (single oral dose)

\begin{tabular}{lccr}
\hline Parameters & Control & BA & HBA \\
\hline WBC $\left(10^{3} / \mathrm{ul}\right)$ & $9.237 \pm 1.03$ & $7.63 \pm 1.28$ & $7.292 \pm 1.29$ \\
RBC $\left(10^{6} / \mathrm{ul}\right)$ & $7.97 \pm 0.14$ & $9.258 \pm 0.3$ & $9.124 \pm 0.26$ \\
HGB $(\mathrm{g} / \mathrm{dl})$ & $11.67 \pm 0.26$ & $12.8 \pm 0.45$ & $13.06 \pm 0.33$ \\
HCT $(\%)$ & $36.72 \pm 1.3$ & $40.8 \pm 1.08$ & $41.36 \pm 0.93$ \\
MCV $(\mathrm{fl})$ & $47.30 \pm 1.26$ & $44.12 \pm 0.7$ & $45.38 \pm 1.05$ \\
MCH $(\mathrm{pq})$ & $14.06 \pm 0.32$ & $13.82 \pm 0.21$ & $14.34 \pm 0.25$ \\
MCHC $(\mathrm{g} / \mathrm{dl})$ & $29.72 \pm 0.45$ & $31.36 \pm 0.33$ & $31.6 \pm 0.29$ \\
PLT $(10 \% / \mathrm{ul})$ & $1409 \pm 149.7$ & $1351 \pm 137.3$ & $1433 \pm 34.3$ \\
NEUT $(\%)$ & $13.8 \pm 2.03$ & $14.96 \pm 2.32$ & $16.96 \pm 2.65$ \\
LYMPH $(\%)$ & $68.81 \pm 12.41$ & $75.34 \pm 2.69$ & $64.24 \pm 10.71$ \\
MONO (\%) & $5.8 \pm 2.22$ & $6.48 \pm 1.02$ & $5.22 \pm 0.65$ \\
EO $(\%)$ & $1.81 \pm 0.01$ & $2.69 \pm 0.13$ & $2.6 \pm 0.18$ \\
BASO $(\%)$ & $0.1 \pm 0.02$ & $0.1 \pm 0.04$ & $0.008 \pm 0.02$ \\
& & & \\
\hline
\end{tabular}

Values are represented as mean \pm S.E.M. ( $n=7 /$ group). Student-NewmanKeul's test and T-test (ANOVA)

to be $1116 \pm 96.78 \mathrm{mg}$ as compared with $1689.95 \pm 88.86 \mathrm{mg}$ of the control group. From the results, it can be inferred that compared with BA showing $28.05 \%$ tumor-growth inhibition at a dose of $50 \mathrm{mg} / \mathrm{kg}$ i.p. HBA is capable of showing higher tumor-growth inhibition of $33.96 \%$ at even lesser dose of $40 \mathrm{mg} / \mathrm{kg}$ i.p. This stresses upon the more potent anticancer potency of HBA molecule relative to BA in EAT model. Under similar conditions, 5-FU, which was used as a positive control, showed $52.05 \%$ tumor regression at a dose of $22 \mathrm{mg} / \mathrm{kg}$ i.p. Comparisons were made between the control and treated groups using the Student's $t$-test.

\section{Discussion}

Cancer is the most deadly disease or, to be more appropriate, a group of diseases responsible for the majority of human deaths all over the globe. ${ }^{32,33}$ As the existing chemotherapeutics still possess some shortcomings such as the offtarget effects. ${ }^{34}$ So, the need of the current scenario of cancer drug development is to develop lead molecules with selective inhibition of cancer cell growth. With the understanding of role of natural products and natural product modification in the present cancer drug discovery, we have synthesized a novel semi-synthetic triazoline derivative of BA (HBA). ${ }^{20}$ In the light of promising therapeutic potential of HBA reported by us, we were enthusiastic to explore the novel insight in deciphering the mechanisms involved in HBA-induced cell cycle arrest and apoptosis culminating in cancer cell growth inhibition. It was observed using different screening methods that HBA exhibited a greater antiproliferative and cytotoxic activity in a concentration- and time-dependent manner that was also confirmed by the inhibition of colony-forming ability of MCF-7 cells by HBA in the present study.

Numerous proteins have been implicated as having a crucial role in metastatic cancers. The present study identified a novel molecule with the ability of selectively killing the cancer cells via the inhibition of the PI3K/AKT signaling pathway in HL-60 cells, THP-1 and MCF-7 that represents an important anticancer target. ${ }^{35}$ In addition, as different PI3K isoforms have markedly different roles in cellular signaling, growth and oncogenic transformation, therefore ablation of a particular isoform will have its own downstream signaling effects. ${ }^{36}$ In the present case, HBA significantly downregulated the expression of both PI3K p110a and p85a in HL-60, THP-1 and MCF-7 cancer cell lines when compared with the untreated control. When comparing the effects of the parent molecule BA on the expression of PI3KP110a and P85a, we found that comparable effects were produced by $\mathrm{BA}$ at 2-3-fold higher concentration than produced by $\mathrm{HBA}$ at 20 and $30 \mu \mathrm{M}$ concentrations. Further moving downstream of PI3K/AKT signaling pathway, $\mathrm{PI} K \mathrm{~K}$ in its active form generates phosphotidyl inositol triphosphate $(\mathrm{PI}(3,4,5) \mathrm{P} 3$. $\mathrm{PI}(3,4,5) \mathrm{P} 3$ brings two $\mathrm{PH}$ domain-containing serine/threonine kinases, phosphoinositide-dependent kinase 1 (PDK1) and AKT into close proximity, phosphorylating AKT and thus activating it. ${ }^{37}$ AKT is the primary mediator of PI3K-initiated signaling and has a number of downstream substrates that may contribute to malignant transformation. ${ }^{13}$ HBA caused appreciable downregulation of $\mathrm{pAKT}$ in a dose-dependent manner in all the three cancer cell lines. Inhibition of pAKT induced by HBA on HL-60, THP-1 and MCF-7 was clearly evident that further explains why significant inhibition of PI3K/AKT increased apoptosis induced by HBA in these cancer cell lines.

As PI3K/AKT pathway is known to induce cell cycle progression. ${ }^{13}$ Cell cycle is regulated by highly multifaceted proteins that include cyclins, CDKs as well as CDKis. ${ }^{38}$ This prompted us to study the expression profile of cyclins in the present study and we could observe that HBA induced cell cycle arrest by downregulating the expression of cyclins $D, E$ and $A$ in HL-60, THP-1 and MCF-7 cells suggests that these proteins have been involved in cell cycle progression in leukemia and breast cancer cell lines employed. Overall, these 
Table 2 In vivo anti cancer activity of BA and HBA

\begin{tabular}{|c|c|c|c|c|c|c|c|}
\hline \multirow[b]{2}{*}{ Treatment groups } & \multicolumn{3}{|c|}{$\begin{array}{l}\text { Average body weights(g) } \\
\text { of animals on days }\end{array}$} & \multicolumn{2}{|c|}{ Day 13} & \multirow[b]{2}{*}{$\begin{array}{l}\% \text { Tumor growth } \\
\text { inhibition }\end{array}$} & \multirow[b]{2}{*}{ Mortality } \\
\hline & 1 & 5 & 9 & $\begin{array}{c}\text { Av. body } \\
\text { weights (g) }\end{array}$ & $\begin{array}{c}\text { Av. tumor } \\
\text { weights (mg) }\end{array}$ & & \\
\hline BA (50 mg/kg i.p.) & 20.14 & 21.71 & 21.81 & 22.57 & $1215.78 \pm 51.8^{\star \star}$ & 28.05 & $0 / 7$ \\
\hline BA (100 mg/kg i.p.) & 20.28 & 21.28 & 22.00 & 22.28 & $1031.5 \pm \overline{5} 4.21^{\text {***}}$ & 39.00 & $0 / 7$ \\
\hline HBA (40 mg/kg i.p.) & 20.42 & 21.42 & 21.85 & 22.70 & $1116 \pm 96.78^{\star \star \star}$ & 33.96 & $0 / 7$ \\
\hline 5-Florouracil-positive control (22 mg/kg i.p.) & $20 / 71$ & 21.42 & 20.71 & 20.85 & $817.5 \pm 33.71^{\star \star \star}$ & 52.05 & $0 / 7$ \\
\hline Normal saline NS (0.2 ml i.p.) & 20.80 & 21.50 & 22.80 & 23.50 & $1689.95 \pm 88.68$ & - & $0 / 10$ \\
\hline
\end{tabular}

Values are mean \pm S.E. $\left(n=7,10\right.$ for control). ${ }^{\star} P<0.05,{ }^{* \star} P<0.01,{ }^{* \star *} P<0.001$ versus normal saline control

results indicate that the decreased expression of cyclins contributes to the PI3K/AKT-mediated $\mathrm{G}_{0} / \mathrm{G}_{1}$ arrest. Importantly, HBA-induced cell cycle arrest is mediated by downregulation of cyclins, which may subsequently result in the decreased activity of CDKis. CDKis appears to be instrumental for maintaining human leukemia and breast cancer cells in the $\mathrm{G}_{0} / \mathrm{G}_{1}$ phase as was evident by the upregulation of p21/cip and p27/kip CDKi in HBA-treated cell lines in the present study. In order to further explore the mechanism of regulation of cell cycle by HBA, we looked into the expression status of $\mathrm{pGSK} 3 \beta$. In our results, substantial downregulation of pGSK3 $\beta$ was observed in a dose-dependent manner keeping this protein in its active unphosphorylated state, suggesting that cell cycle arrest stimulated by HBA is induced by CDKi, which is encouraged by GSK3 $\beta$. To further examine the effect of HBA on cell cycle in leukemia and breast cancer cells, flow cytometry analyses were performed, where results showed cells were arrested in the $G_{0} / G_{1}$ phase of the cell cycle followed by a significant increase of THP-1, HL-60 and MCF-7 cells in the sub- $\mathrm{G}_{0} / \mathrm{G}_{1}$ phase.

The mitochondrial involvement has been validated by looking into the expression of mitochondrial bcl-2 family proteins. AKT can modulate bad activity by phosphorylating at Ser ${ }^{112}, 39$ and phosphorylated Bad then dissociates from bcl2 to form a complex with the 14-3-3 adaptor protein leading to cell survival. ${ }^{40}$ We observed decrease in the expression of bcl2 protein in all the three cancer cell lines that was associated with elevated levels of bax protein in a dosedependent manner. Moreover, the involvement of mitochondria was also confirmed by the observed decrease in the expression of mitochondrial cytochrome $c$ in HL-60 cells. The modulation in the expression of bcl2 family proteins lead to generation of ROS, which induced disruption of mitochondrial function with concurrent loss of $\Delta \psi_{\mathrm{m}}$. In addition, HBA-induced activation of caspases 8, 9 and 3 in HL-60, THP-1 and MCF-7 cells suggested both mitochondrial-dependent and -independent factors responsible for its apoptotic potential; however, the mitochondrial involvement is more pronounced. Mitochondrial apoptosis is primarily regulated by molecular interactions between different members of the bcl-2 family. There exist a link between mitochondrial and receptor-mediated apoptosis, and this link is provided by active caspase-8. This was observed in the present study where activation of caspase 8 helped in the pronounced mitochondrial-mediated apoptotic cell death in HL-60, THP-1 and MCF-7 cells. Subsequently, the activation of caspase cascade leads to the formation of cleaved products of PARP. Furthermore, NFKB is a transcription factor that can be induced by a variety of signals. ${ }^{41} \mathrm{NF} K \mathrm{~B}$ expression status has been checked in HBA-treated HL-60, THP-1 and MCF-7 cells, and we could find appreciable decrease in the expression of $\mathrm{NF}_{K} \mathrm{~B}$ transcriptional factor in the present study. Our results demonstrate that treatment of HL-60 cells with HBA caused apoptotic cell death as was evidenced by DNA fragmentation in a concentrationdependent manner. Moreover, the induction of apoptosis was specific to leukemia cells only as no such laddering pattern had been observed in $\mathrm{CV}-1$ cells, which is a normal monkey kidney cell line. ${ }^{20}$

Keeping the importance of the molecule into consideration, the acute toxicity studies were carried out. The study was designed and aimed to evaluate whether exposure of HBA is safe and not altering the activities of major physiological systems in comparison to BA, with the intention that the results would provide information on the safety of the compound. It has been observed that both BA and HBA were toxicologically safe as both of them did not cause any mortality or any adverse effect during testing. Furthermore, the biochemical parameters studied do not show any significant deviation from the control values. Therefore the present findings suggest that both HBA and BA are non-toxic compounds upto the dose of $2000 \mathrm{mg} / \mathrm{kg}$ body weight that correlates with the observation obtained under in vitro conditions where no apoptosis has been observed in normal monkey kidney (CV-1) cells treated with $\mathrm{HBA} .{ }^{20}$ Furthermore, in vitro studies paralleled with the in vivo testing of $\mathrm{HBA}$ and $\mathrm{BA}$ against murine tumor models Ehrlich tumor (solid). The tumor-growth inhibition observed after treatment with HBA and BA showed substantial decrease. Comparing the in vivo anti-tumor potential of HBA with $\mathrm{BA}$, we could find that HBA showed comparatively higher tumor-growth inhibition (33.96\%) than BA (28.05\%) when used at even lesser dose $40 \mathrm{mg} / \mathrm{kg}$ i.p. than BA (50 mg/kg i.p.). Therefore in vitro and in vivo studies highlighted the usefulness of HBA in treating human leukemia and breast cancers specifically by targeting the PI3K/AKT pathway.

In conclusion, our study tried to unveil a therapeutic potential of HBA, a triazoline derivative of $\mathrm{BA}$ in the tumor biology. We showed that the robust inhibition of the PI3K/AKT pathway can inhibit tumor progression by regulating the expression of cell cycle regulatory proteins and promote cell death in apoptosis-resistant cancers and therefore raise the potential usefulness of HBA as an excellent anticancer therapeutic candidate. 


\section{Materials and Methods}

RPMI-1640 medium, Rh-123, propidium iodide (PI), 3-(4,5-dimethylthiazole-2-yl)-2,5diphenyltetrazolium bromide (MTT), eukaryotic protease inhibitor cocktail, penicillin, streptomycin, camptothecin, fetal bovine serum, sodium bicarbonate, phosphatebuffered saline (PBS), Tris buffer saline with tween-20 (TBST), radio immune precipitation assay lysis buffer, trypsin, electrophoresis reagents, protein estimation kit and protein marker were purchased from Sigma Aldrich Co. (St. Louis, MO, USA). Hyper film is from Amersham Biosciences (Buckinghamshire, UK). DNase-free RNase is from USB Corporation (Cleveland, OH, USA). Tris buffer and bromophenol blue were procured from Himedia (Mumbai, India). Glacial acetic acid was purchased from Fisher Scientific (Waltham, MA, USA), and trichloroacetic acid from Merck Specialties Private Ltd. (New Delhi, India). Annexin V-FITC apoptosis detection kit, anti-pAKT, anti-tAKT, anti-cyclin D, anti-pGSK3 $\beta$, goat anti-rabbit IgG HRP, rabbit-antigoat IgG HRP, goat anti-mouse IgG HRP and goat anti-mouse lgG-TR were purchased from Santa Cruz Biotechnology (Dallas, TX, USA). Anti-NF-kB anti-PI3K p110 $\alpha$ and p85 $\alpha$, anti-Bax, anti-Bcl2, anti-caspase 8, anti-p27, anti-p21, anti-PARP antibodies and ECL Plus western blotting detection kit were purchased from Millipore Life Science Research (Darmstadt, Germany). Anti- $\beta$-actin antibody were purchased from Sigma Aldrich Co.

Cell culture, growth conditions and treatment. Human promyelocytic leukemia cell line (HL-60), human breast cancer cell line (MCF-7) and human acute monocytic leukemia cell line (THP-1) used in the study were purchased from European Collection of Cell Culture (ECACC, Salisbury, UK). Cells were grown in RPMI-1640/MEM/DMEM containing 10\% FCS, 100 unit Penicillin/100 $\mu \mathrm{g}$ Streptomycin per $\mathrm{ml}$ medium. Cells were grown in $\mathrm{CO}_{2}$ incubator (Thermo Scientific, Waltham, MA, USA) at $37^{\circ} \mathrm{C}$ with $98 \%$ humidity and $5 \% \mathrm{CO}_{2}$ gas environment. Cells were treated with $\mathrm{BA}$ and its different structural analogs dissolved in DMSO while the untreated control cultures received only the vehicle (DMSO, $<0.2 \%$ ).

Cell proliferation assay. HL-60, THP-1 and MCF-7 cells were grown in 96well plates at a density of $1.5 \times 10^{4} \mathrm{cells} /$ well/100 $\mu$ land exposed to 1, 510,20 and $30 \mu \mathrm{M}$ concentration of HBA and 1, 1020,30 and $40 \mu \mathrm{M}$ concentration of parent BA molecule for the different time intervals thereafter, and $20 \mu \mathrm{l}$ of MTT solution $(2.5 \mathrm{mg} / \mathrm{ml})$ was added to each well and incubated at $37^{\circ} \mathrm{C}$ for $3-4 \mathrm{~h}$ in a humidified atmosphere containing $5 \% \mathrm{CO}_{2}$. The plates were then centrifuged at 1500 r.p.m. for $15 \mathrm{~min}$, and the supernatant was discarded while the MTT-formazon crystals were dissolved in $150 \mu$ l DMSO. The OD was measured at $570 \mathrm{~nm}$, with reference wavelength of $620 \mathrm{~nm}^{20}$

In vitro clonogenic assay. Clonogenic assay was performed to evaluate the ability of a cell to grow into a colony. MCF-7 cells were harvested from logarithmically growing stock cultures and plated at the required final clonogenic dilutions prior to treatment. After $24 \mathrm{~h}$, the cells were treated with the indicated concentrations of the compound for another $24 \mathrm{~h}$. After treatment, the plates were placed in an incubator for a time equivalent to at least six potential cell divisions (to give colonies of $>50$ cells). After this, the medium was aspirated from the plates so as not to disturb the colonies. Plates are then washed with PBS, and then a mixture of $6 \%$ glutaraldehyde and $0.5 \%$ crystal violet were added for $30 \mathrm{~min}$ to allow sufficient staining. The mixture was removed after $30 \mathrm{~min}$, and the plates were washed with water and allowed to dry at room temperature. ${ }^{20}$

Preparation of whole-cell lysates for immunoblotting. Cells $\left(20 \times 10^{5} /\right.$ well/2 $\left.\mathrm{ml}\right)$ were collected, washed with cold PBS and incubated with cold lysis buffer and $1 \%(\mathrm{v} / \mathrm{v})$ eukaryotic protease inhibitor cocktail for $45 \mathrm{~min}$ on ice. Cells were centrifuged at $14000 \mathrm{~g}$ for $15 \mathrm{~min}$ to pallet the cell debris. Supernatant were transferred to a new tube and used as whole-cell lysates for western blotting analysis of various proteins.

Protein measurement. Protein was measured by employing Sigma QuantiPro BCA kit using bovine serum albumin as the standard as per the instruction provided in the manual.

Western blotting analysis. The whole-cell protein lysates were subjected to SDS-PAGE. Protein aliquots $(100 \mu \mathrm{g})$ were resolved on SDS-PAGE at $100 \mathrm{~V}$ for $2-3 \mathrm{~h}$ at room temperature and then electrotransferred to PVDF membrane at $120 \mathrm{~V}$ for $1.5-2 \mathrm{~h}$ maintained at $4{ }^{\circ} \mathrm{C}$. Non-specific binding was blocked by incubation with $5 \%$ non-fat milk in PBS for $1 \mathrm{~h}$ at room temperature. Blocking of the membrane for phosphorylated antibodies was done by using $5 \%$ bovine serum albumin in PBS for
$1 \mathrm{~h}$. Blots were probed with respective primary antibodies overnight and washed three times with Tris buffer saline with $2 \%$ Tween-20 each for 5 min. ${ }^{42}$ The blots were then incubated with horseradish peroxidase-conjugated mouse, rabbit or goat secondary antibodies for $1 \mathrm{~h}$, and again same washing steps were repeated each for 30 min. Signals were detected using ECL plus chemiluminescence's kit on X-ray film.

DNA content and cell cycle phase distribution. HL-60, THP-1 and MCF-7 cells were seeded in six-well plates at a concentration of $\left(10 \times 10^{5} \mathrm{cells} /\right.$ well/ $2 \mathrm{ml}$ ) and treated with the indicated concentrations of HBA. After $24 \mathrm{~h}$, cells were collected, washed in PBS and fixed in $70 \%$ cold ethanol overnight. Cells were again washed with PBS and subjected to RNase digestion $(400 \mu \mathrm{g} / \mathrm{ml})$, and finally, cells were incubated with PI $(10 \mu \mathrm{g} / \mathrm{ml})$. Cells are then analyzed immediately on flow cytometer FACS Diva (Becton Dickinson, Franklin Lakes, NJ, USA). The fluorescence intensity of sub- $G_{0} / G_{1}$ cell fraction represents the apoptotic cell population. ${ }^{43}$

Flow cytometric analysis of apoptosis and necrosis using annexin V/PI dual staining. HL-60, THP-1 and MCF-7 cells after treatments with different concentrations of HBA for $24 \mathrm{~h}$ were collected and washed twice with cold PBS and resuspened in $400 \mu \mathrm{l} 1 \times$ binding buffer. Thereafter $2 \mu \mathrm{l}$ of annexin V-FITC antibody were added to the cell suspension, and the cells were incubated for 30 min at $37^{\circ} \mathrm{C}$. Ten microliters of $\mathrm{PI}$ was added immediately before flow cytometric analysis. PI was used to distinguish cells that have lost membrane integrity. The cells were scanned for fluorescence intensity in FITC and PI channels. ${ }^{44}$

Flow cytometric measurement of intracellular peroxides (ROS) generation in HL-60 cells. Intracellular peroxides level was determined by using 2, 7-dichlorofluoresceindiacetate. An increase in green fluorescence intensity is used to quantify the generation of intracellular ROS. Cells $\left(10 \times 10^{5} / 2 \mathrm{ml} / \mathrm{six}\right.$-well plates) were incubated with different concentrations of HBA. Before $30 \mathrm{~min}$ of the termination of the experiment, cells were incubated with DCFH-DA $(5 \mu \mathrm{M})$. Cells were washed in PBS and centrifuged at 1500 r.p.m. for $5 \mathrm{~min}$ and suspended in PBS. The green DCF-fluorescence was analyzed in the FL-1 channel (excitation $\lambda$ $488 \mathrm{~nm}$; emission $\lambda 535 \mathrm{~nm}){ }^{44}$

Measurement of mitochondrial membrane potential for cellular energy status. Changes in $\Delta \Psi_{\mathrm{m}}$ as a result of mitochondrial perturbation were measured with Rh-123 staining. HL-60, THP-1 and MCF-7 cells at a density of $(10 \times 10 \% / \mathrm{ml} /$ well) were grown in six-well plates and treated with the indicated concentrations of HBA. Rh-123 $(2 \mu \mathrm{M})$ was added 30 min before the termination of experiment. Cells were washed in PBS and centrifuged at 1500 r.p.m. for 5 min and suspended in PBS. The decrease in intensity of fluorescence from 10000 events because of mitochondrial membrane potential loss was analyzed in FITC channel on flow cytometer. ${ }^{45}$

In vitro cell migration assay. The wound-healing assay is simple, inexpensive and one of the earliest developed methods to study directional cell migration in vitro. The basic steps involve creating a 'wound' in a cell monolayer, capturing the images at the beginning and at regular intervals during cell migration to close the wound and comparing the images to quantify the migration rate of the cells. In all, $30 \times 10^{4} \mathrm{cell} / \mathrm{m} / \mathrm{m} /$ well were seeded in six-well plates. Cells were then wounded by scratching with a 1000- $\mu$ l pipette tip and the cell was washed three times with PBS to remove cell debris. HBA was added at the desired concentration, and the plates were incubated in the $\mathrm{CO}_{2}$ incubator for another $24 \mathrm{~h}$. After the completion of the treatment, fresh medium was added into the plates, and the plates were again incubated till the control wound gets completely healed. The wounds were photographed ( $\times 10$ objective) at 0 and $24 \mathrm{~h}$, and healing was quantified by measuring the distance between the edges of the wound. ${ }^{26}$

Pharmacodynamics and acute toxicity measurements. BA and HBA were evaluated for oral acute toxicity as per the rules of the Organization for Economic Cooperation and Development guidelines in female Swiss mice. ${ }^{46}$ Briefly, five female swiss mice per group received BA and HBA starting at $2000 \mathrm{mg} / \mathrm{kg}$ via oral route. The animals were kept in perspex chambers and monitored for any toxic symptoms for the first $4 \mathrm{~h}$ and then intermittently up to $24 \mathrm{~h}$ as described previously. ${ }^{47}$ Animals were further observed daily for the next 13 days for mortality or observable toxicity, if any. Finally, the number of survivors was noted. Body weight changes were recorded weekly, and feed and water intake was measured on daily 
basis. At the end of the study, the serum was assayed for determination of various biochemical parameters such as glucose, alkaline phosphatase, urea, and so on using commercial kits (Erba, Manheim, Germany). Moreover, investigation of the whole blood was done for various hematological parameters such as red blood cells, white blood cells, hemoglobin, platelet count, hematocrit, mean corpuscular volume, mean corpuscular hemoglobin concentration, neutrophils, lymphocytes, monocytes, eoisinophils and basophils. ${ }^{48}$

In vivo anti-tumor activity against Ehrlich tumor solid. In vivo antitumor activity of BA and HBA was evaluated in murine tumor models. Swiss albino mice, were maintained at $23^{\circ} \mathrm{C}$ temperature with 20-25 complete air changes with $100 \%$ fresh air at $50-60 \%$ relative humidity. The number of animals used in the present study was approved by the Institutional Animal Ethics Committee, Indian Institute of Integrative Medicine, Jammu. EAC cells were collected from the peritoneal cavity of the Swiss mice harboring 8-10-days-old ascitic tumor. On day 0 , $10 \times 10^{6}$ EAC cells were injected intramuscularly in the Swiss albino mice $(n=38)$ on the right thigh. The next day, animals were randomized and divided into five different groups. Four treatment groups contained 7 animals each and one control group contained 10 animals. The first test group was treated with $50 \mathrm{mg} / \mathrm{kg}$, i.p. BA, second test group with $100 \mathrm{mg} / \mathrm{kg}$ i.p. BA and third group was received $40 \mathrm{mg} / \mathrm{kg}$ i.p. HBA. Fourth treatment group received 5 -fluorouracil $(22 \mathrm{mg} / \mathrm{kg}$, i.p.), and it served as a positive control. The control group was similarly administered normal saline $(0.2 \mathrm{ml}$, i.p.). On day 9 and 13 , tumor-bearing thigh of each animal was shaved, and the longest and shortest diameter of the tumors were measured with the help of a vernier caliper. Tumor weight of each animal was calculated using the formula.

$$
\text { Tumor weight }(\mathrm{mg})=\frac{\text { Length }(\mathrm{mm}) \times[\text { Width }(\mathrm{mm})]^{2}}{2}
$$

The percentage tumor growth inhibition was calculated on day 13 by comparing the average value of the treated groups with that of the control group. Tumor growth in saline-treated animals was taken to be $100 \%$

Statistical analysis. Statistical analysis was done by using the Student's $t$-test, and $P$-value $<0.05$ was considered to be significant, with ${ }^{*} P<0.05$, ${ }^{* *} P<0.01$ and ${ }^{* * *} P<0.001$.

\section{Conflict of Interest}

The authors declare no conflict of interest.

Acknowledgements. The authors wish to thank the Director, CSIR-IIIM Jammu, Dr Ram A Vishwakarma for his generous financial support from CSIR (BSC-0205 and MLP-6002). Rabiya Majeed thanks CSIR, New Delhi for the award of senior research fellowship. This article has been communicated under Institutional Publication No. IIIM/1598/2013.

1. Fernandes J, Castilho RO, da Costa MR, Wagner-Souza K, Coelho Kaplan MA, Gattass CR. Pentacyclic triterpenes from Chrysobalanaceae species: cytotoxicity on multidrug resistan and sensitive leukemia cell lines. Cancer Lett 2003; 190: 165-169.

2. Jassim S, Naji MA. Novel antiviral agents: a medicinal plant perspective. J Appl Microbio 2003; 95: 412-427.

3. Fidock DA, Rosenthal PJ, Croft SL, Brun R, Nwaka S. Antimalarial drug discovery: efficacy models for compound screening. Nat Rev Drug Discov 2004; 3: 509-520.

4. Gordaliza M. Natural products as leads to anticancer drugs. Clin Transl Oncol 2007; 9 : 767-776.

5. Gao Y, Jia Z, Kong X, Li Q, Chang DZ, Wei D et al. Combining betulinic acid and mithramycin a effectively suppresses pancreatic cancer by inhibiting proliferation, invasion, and angiogenesis. Cancer Res 2011; 71: 5182-5193.

6. Mertens-Talcott SU, Noratto GD, Li X, Angel-Morales G, Bertoldi MC, Safe S. Betulinic acid decreases ER-negative breast cancer cell growth in vitro and in vivo: role of $S p$ transcription factors and microRNA-27a: ZBTB10. Mol Carcinog 2013; 52: 591-602.

7. Fulda S, Kroemer G. Targeting mitochondrial apoptosis by betulinic acid in human cancers Drug Discov Today 2009; 14: 885-890.

8. Tan Y, Yu R, Pezzuto JM. Betulinic acid-induced programmed cell death in human melanoma cells involves mitogen-activated protein kinase activation. Clin Cancer Res 2003; 9 : 2866-2875.

9. Kasperczyk H, La Ferla-Brühl K, Westhoff MA, Behrend L, Zwacka RM, Debatin K-M et al. Betulinic acid as new activator of NF- $\kappa \mathrm{B}$ : molecular mechanisms and implications for cancer therapy. Oncogene 2005; 24: 6945-6956.
10. Fulda S, Friesen $C$, Los M, Scaffidi C, Mier W, Benedict M et al. Betulinic acid triggers CD95 (APO-1/Fas)-and p53-independent apoptosis via activation of caspases in neuroectodermal tumors. Cancer Res 1997; 57: 4956-4964.

11. Carnero A. The PKB/AKT pathway in cancer. Curr Pharm Des 2010; 16: 34-44.

12. Rzeski W, Stepulak A, Szymański M, Sifringer M, Kaczor J, Wejksza K et al. Betulinic acid decreases expression of bcl-2 and cyclin D1, inhibits proliferation, migration and induces apoptosis in cancer cells. Naunyn Schmiedebergs Arch Pharmacol 2006; 374: $11-20$.

13. Chang F, Lee J, Navolanic P, Steelman L, Shelton J, Blalock W et al. Involvement of PI3K/Akt pathway in cell cycle progression, apoptosis, and neoplastic transformation: a target for cancer chemotherapy. Leukemia 2003; 17: 590-603.

14. Zhang S, Zhang Y, Zhuang Y, Wang J, Ye J, Zhang S et al. Matrine induces apoptosis in human acute myeloid leukemia cells via the mitochondrial pathway and Akt inactivation. PLoS One 2012; 7: e46853.

15. Udeani GO, Zhao GM, Geun Shin Y, Cooke BP, Graham J, Beecher CW et al Pharmacokinetics and tissue distribution of betulinic acid in CD-1 mice1. Biopharm Drug Dispos 1999; 20: 379-383.

16. Rajendran $P$, Jaggi $M$, Singh MK, Mukherjee R, Burman AC. Pharmacological evaluation of C-3 modified Betulinic acid derivatives with potent anticancer activity. Invest New Drugs 2008; 26: 25-34.

17. Kvasnica M, Sarek J, Klinotova E, Dzubak P, Hajduch M. Synthesis of phthalates of betulinic acid and betulin with cytotoxic activity. Bioorg Med Chem 2005; 13: 3447-3454.

18. Gauthier C, Legault J, Lavoie S, Rondeau S, Tremblay S, Pichette A. Synthesis and cytotoxicity of bidesmosidic betulin and betulinic acid saponins. J Nat Prod 2008; 72 : 72-81.

19. Rajendran $P$, Jaggi M, Singh MK, Mukherjee R, Burman AC. Pharmacological evaluation of C-3 modified Betulinic acid derivatives with potent anticancer activity. Invest New Drugs 2008; 26: 25-34.

20. Majeed R, Sangwan PL, Chinthakindi PK, Khan I, Dangroo NA, Thota N et al. Synthesis of 3-O-propargylated betulinic acid and its 1,2,3-triazoles as potential apoptotic agents. Eur J Med Chem 2013: 63: 782-792.

21. da Silva I, Martins $P$, da Silva E, Ferreira S, Ferreira V, da Costa K et al. Synthesis of $1 \mathrm{H}-1,2$, 3-triazoles and study of their antifungal and cytotoxicity activities. Med Chem 2013; 9: $1085-1090$.

22. LoPiccolo J, Blumenthal GM, Bernstein WB, Dennis PA. Targeting the PI3K/Akt/mTOR pathway: effective combinations and clinical considerations. Drug Resist Updat 2008; 11: 32-50.

23. Serra V, Markman B, Scaltriti M, Eichhorn PJ, Valero V, Guzman M et al. NVP-BEZ235, a dual PI3K/mTOR inhibitor, prevents PI3K signaling and inhibits the growth of cancer cells with activating PI3K mutations. Cancer Res 2008; 68: 8022-8030.

24. Nakayama KI, Nakayama K. Ubiquitin ligases: cell-cycle control and cancer. Nat Rev Cancer 2006; 6: 369-381.

25. Holbro T, Civenni G, Hynes NE. The ErbB receptors and their role in cancer progression. Exp Cell Res 2003; 284: 99-110.

26. Momiyama M, Suetsugu A, Kimura H, Chishima T, Bouvet M, Endo I et al. Dynamic subcellular imaging of cancer cell mitosis in the brain of live mice. Anticancer Res 2013; 33: 1367-1371.

27. Hoffman RM, Yang M. Subcellular imaging in the live mouse. Nat Protoc 2006; 1: 775-782.

28. Yamamoto $\mathrm{N}$, Jiang $\mathrm{P}$, Yang $\mathrm{M}, \mathrm{Xu} \mathrm{M}$, Yamauchi $\mathrm{K}$, Tsuchiya $\mathrm{H}$ et al. Cellular dynamics visualized in live cells in vitro and in vivo by differential dual-color nuclear-cytoplasmic fluorescent-protein expression. Cancer Res 2004; 64: 4251-4256.

29. Gross A, McDonnell JM, Korsmeyer SJ. BCL-2 family members and the mitochondria in apoptosis. Genes Dev 1999; 13: 1899-1911.

30. Gupta GP, Massague J. Cancer metastasis: building a framework. Cell 2006; 127: 679-695

31. Creton S, Dewhurst IC, Earl LK, Gehen SC, Guest RL, Hotchkiss JA et al. Acute toxicity testing of chemicals-Opportunities to avoid redundant testing and use alternative approaches. Crit Rev Toxicol 2010; 40: 50-83.

32. Siegel R, Naishadham D, Jemal A. Cancer statistics, 2013. CA Cancer J Clin 2013; 63: 11-30.

33. Sarkar FH, Li Y. Using chemopreventive agents to enhance the efficacy of cancer therapy. Cancer Res 2006; 66: 3347-3350.

34. Huttunen KM, Raunio H, Rautio J. Prodrugs-from serendipity to rational design. Pharmacol Rev 2011; 63: 750-771.

35. Cleary JM, Shapiro Gl. Development of phosphoinositide-3 kinase pathway inhibitors for advanced cancer. Curr Oncol Rep 2010; 12: 87-94.

36. Yuan TL, Cantley LC. PI3K pathway alterations in cancer: variations on a theme. Oncogene 2008; 27: 5497-5510.

37. Qazi AK, Hussain A, Hamid A, Qurishi Y, Majeed R, Ahmad M et al. Recent development in targeting PI3K-Akt-mTOR signaling for anticancer therapeutic strategies. Anticancer Agents Med Chem 2013; 13: 1552-1564.

38. Nurse P. A long twentieth century of the cell cycle and beyond. Cell 2000; 100: 71-78.

39. Harada H, Andersen JS, Mann M, Terada N, Korsmeyer SJ. p70S6 kinase signals cell survival as well as growth, inactivating the pro-apoptotic molecule BAD. Proc Natl Acad Sci 2001; 98: 9666-9670.

40. Fang X, Yu S, Eder A, Mao M, Bast Jr RC, Boyd D et al. Regulation of BAD phosphorylation at serine 112 by the Ras-mitogen-activated protein kinase pathway. Oncogene 1999; 18: $6635-6640$. 
41. Karin $M$, Delhase $M$. The $I_{\kappa} B$ kinase $(I K K)$ and $N F-\kappa B$ : key elements of proinflammatory signalling. Semin Immunol 2000; 2000: 85-98.

42. Yu Z, Li W. Induction of apoptosis by puerarin in colon cancer HT-29 cells. Cancer Lett 2006; 238: $53-60$.

43. Vermes I, Haanen C, Steffens-Nakken H, Reutellingsperger C. A novel assay for apoptosis flow cytometric detection of phosphatidylserine expression on early apoptotic cells using fluorescein labelled annexin V. J Immunol Methods 1995; 184: 39-51.

44. Crow JP. Dichlorodihydrofluorescein and dihydrorhodamine 123 are sensitive indicators of peroxynitrite in vitro: implications for intracellular measurement of reactive nitrogen and oxygen species. Nitric Oxide 1997; 1: 145-157.

45. Lin H-I, Lee Y-J, Chen B-F, Tsai M-C, Lu J-L, Chou C-J et al. Involvement of Bcl-2 family, cytochrome $c$ and caspase 3 in induction of apoptosis by beauvericin in human non-small cell lung cancer cells. Cancer Lett 2005; 230: 248-259.

46. Thanabhorn S, Jaijoy K, Thamaree S, Ingkaninan K, Panthong A. Acute and subacute toxicity study of the ethanol extract from Lonicera japonica Thunb. J Ethnopharmacol 2006; 107: 370-373.

47. Rayees S, Sharma R, Singh G, Najar IA, Singh A, Ahamad DB et al. Acute, sub-acute and general pharmacological evaluation of 5-(3, 4-methylenedioxyphenyl)-4-ethyl-2E,
4E-pentadienoic acid piperidide (SK-20): a novel drug bioavailability enhancer. Environ Toxicol Pharmacol 2013; 35: 347-359.

48. Brock WJ, Schroeder RE, McKnight CA, VanSteenhouse JL, Nyberg JM. Oral repeat dose and reproductive toxicity of the chlorinated flame retardant Dechlorane Plus. Int $J$ Toxicol 2010; 29: 582-593.

(c) (i) Cell Death and Disease is an open-access journal published by Nature Publishing Group. This work is licensed under a Creative Commons Attribution 3.0 Unported License. The images or other third party material in this article are included in the article's Creative Commons license, unless indicated otherwise in the credit line; if the material is not included under the Creative Commons license, users will need to obtain permission from the license holder to reproduce the material. To view a copy of this license, visit http:// creativecommons.org/licenses/by/3.0/ 